\title{
Review
}

\section{Molecular and cellular basis of small- and intermediate-conductance, calcium-activated potassium channel function in the brain}

\author{
P. Pedarzani* and M. Stocker \\ Research Department of Neuroscience, Physiology and Pharmacology, University College London, \\ Gower Street, London WC1E 6BT (UK), e-mail: p.pedarzani@ucl.ac.uk
}

Received 23 April 2008; received after revision 29 May 2008; accepted 4 June 2008

Online First 4 July 2008

\begin{abstract}
Small conductance calcium-activated potassium (SK or $\mathrm{K}_{\mathrm{Ca}} 2$ ) channels link intracellular calcium transients to membrane potential changes. SK channel subtypes present different pharmacology and distribution in the nervous system. The selective blocker apamin, SK enhancers and mice lacking specific SK channel subunits have revealed multifaceted functions of these channels in neurons, glia and cerebral blood vessels. SK channels regulate neuronal firing by contributing to the afterhyperpolarization following action potentials and mediating $\mathrm{I}_{\mathrm{AHB}}$ and partake in a
\end{abstract}

calcium-mediated feedback loop with NMDA receptors, controlling the threshold for induction of hippocampal long-term potentiation. The function of distinct SK channel subtypes in different neurons often results from their specific coupling to different calcium sources. The prominent role of SK channels in the modulation of excitability and synaptic function of limbic, dopaminergic and cerebellar neurons hints at their possible involvement in neuronal dysfunction, either as part of the causal mechanism or as potential therapeutic targets.

Keywords. Calcium-activated potassium channel, afterhyperpolarization, $\mathrm{I}_{\mathrm{AHP}}$, apamin, long-term potentiation, pacemaking neuron, glial cell, cerebral blood vessel endothelium.

\section{An introduction to small-conductance $\mathrm{Ca}^{2+}$-activated $\mathrm{K}^{+}$channels (SK channels)}

\section{Molecular physiology of SK channels \\ Potassium currents purely activated by raises in the intracellular concentration of calcium and insensitive to membrane voltage have been characterized in different types of neurons, where they modulate the firing patterns of action potentials, and thereby play a pivotal role in signal encoding in a concerted action with other ion channels. $\mathrm{Ca}^{2+}$-activated $\mathrm{K}^{+}$currents}

* Corresponding author. display heterogeneous kinetic and pharmacological properties, due to different types of $\mathrm{Ca}^{2+}$-activated $\mathrm{K}^{+}$ channels that mediate them (reviewed in [1-7]).

Large-conductance $\mathrm{Ca}^{2+}$-activated $\mathrm{K}^{+}$channels $(\mathrm{BK}$ or maxi-K channels; $\left.\mathrm{K}_{\mathrm{Ca}} 1.1\right)$ were the first $\mathrm{Ca}^{2+}$ dependent $\mathrm{K}^{+}$channels to be identified in single channel recordings $[8,9]$. BK channels have a single channel conductance of around $100 \mathrm{pS}$ under physiological conditions, which can reach $250 \mathrm{pS}$ when the extracellular and intracellular potassium concentrations are equal. They are activated by voltage and their open probability is modulated by $\mathrm{Ca}^{2+}$. They are widely expressed in different tissues, including different cell types of the nervous system. A more detailed 
description of BK channels and BK-mediated currents can be found in recent reviews [10-17].

Three members of the small conductance, $\mathrm{Ca}^{2+}$ activated $\mathrm{K}^{+}$channel $(\mathrm{SK})$ family, SK1 $\left(\mathrm{K}_{\mathrm{Ca}} 2.1\right)$, SK2 $\left(\mathrm{K}_{\mathrm{Ca}} 2.2\right)$ and SK3 $\left(\mathrm{K}_{\mathrm{Ca}} 2.3\right)$, were cloned in 1996 by Adelman and colleagues [18], shortly followed by the cloning of the intermediate conductance, $\mathrm{Ca}^{2+}$-activated $\mathrm{K}^{+}$channel (IK, SK4, $\mathrm{K}_{\mathrm{Ca}} 3.1$ ) [19-21]. Splice variants have been identified for the three SK channel genes. In the mouse brain, for example, splice variants have been identified that may lead to up to 16 different SK1 polypeptides [22] and two SK2 $\alpha$-subunits with $\mathrm{N}$ termini of different length [23]. Three splice variants have been described for SK3, two of which can be found in the human brain $[24,25]$. The biophysical characterization in heterologous expression systems showed the voltage independence of SK and IK channels and a half maximal activation by $\sim 300 \mathrm{nM}$ free calcium [19-21, 26]. Under recording conditions using concentrations of $\mathrm{K}^{+}$higher than $100 \mathrm{mM}$ on both sides of the membrane, SK channels display a single channel conductance of $\sim 10 \mathrm{pS}[18,27]$, whereas the IK channel shows a larger single channel conductance of 33-42 pS [20,21]. The general topology of SK and IK channels is similar to that of voltage-gated potassium channels of the Shaker superfamily, with six transmembrane spanning regions (S1-S6) and the conducting pore located between S5 and S6 [18-21]. The gating is conferred upon SK and IK channels by $\mathrm{Ca}^{2+}$ binding to calmodulin, which is constitutively bound to the carboxy-terminus of each channel subunit [26, 28-30].

Detection of RNA by Northern analysis, in situ hybridization or RT-PCR analysis and protein by immunohistochemistry have revealed that SK1, SK2, and SK3 channels are expressed in the central (CNS) and peripheral (PNS) nervous system [18, 31-38], while IK seems not to be present in central neurons, but is expressed in blood and epithelial cells [19-21, 39], and in peripheral sensory, sympathetic and enteric neurons [37, 38, 40-43]. In situ hybridization and immunohistochemistry studies on brain tissue from adult rat and mouse have shown further that the SK1, SK2 and SK3 channel subunits have partially overlapping but clearly distinct distribution patterns, with SK1 and SK2 frequently expressed in the same neurons, and SK3 presenting a complementary distribution [32, 34-36]. Moreover, immunohistochemical analysis has suggested that SK 3 might be localized in presynaptic terminals at the neuromuscular junction [44] and in hippocampal neuronal cultures [45]. Altogether, these studies suggest that SK channels formed by specific subunits influence neuronal excitability and function in different brain regions and possibly, on a cellular level, in different neuronal compartments.

\section{Pharmacology of SK channels}

The bee venom toxin apamin is the prototypical, highly specific blocker of SK channels and SK channel subtypes vary in their sensitivities for apamin. This pharmacological difference has been used, in combination with the above-mentioned expression data, to distinguish the contribution of the various SK channels in different physiological contexts. The human SK1 (hSK1) channels are the least sensitive $\left(\mathrm{IC}_{50}\right.$ : 0.7-12 nM; Table 1), the SK2 channels, independently of the species (human, rat, mouse), are the most sensitive $\left(\mathrm{IC}_{50}: 27-140 \mathrm{pM}\right.$; Table 1$)$, and the SK3 channels present an intermediate sensitivity to apa$\min \left(\mathrm{IC}_{50}: 0.6-4 \mathrm{nM}\right.$; Table 1). The rat SK1 channel (rSK1) does not form functional homomultimeric channels in expression systems [46-48]. However, chimeric channel subunits containing the transmembrane domain of rSK1, including the pore region, and at least the intracellular carboxy-terminus of SK2 or hSK1 form functional channels [48]. This rSK1 chimera furthered our understanding on the mechanism by which apamin and potentially other toxins block SK channels, because it showed a 25-fold reduction in apamin sensitivity, despite having an identical primary sequence to hSK1 in the pore region. The reduced apamin sensitivity was surprising because the molecular determinants for toxins blocking $\mathrm{K}^{+}$channels are located in the pore region between the transmembrane segments S5 and S6. A further analysis revealed that not only amino acids of the pore region [49], but also a residue located in the extracellular loop between the transmembrane segments S3 and S4 influence the apamin sensitivity of SK channels [50]. We think that this observation might hold the key to the explanation as to why certain toxins (maurotoxin, Pi1, PO1 and Tsk) potently displace ${ }^{125} \mathrm{I}-$ labeled apamin binding [51-56], but show little or no block of SK channel-mediated currents [57]. Beside apamin, scorpion toxins also specifically target SK channels. These include scyllatoxin (leiurotoxin I), isolated from the scorpion Leiurus quinquestriatus [58-60], P05 from Androctonus mauretanicus [61], and tamapin from Mesobuthus tamulus [62] (Table 1). Moreover, all three SK channel subtypes are also blocked by a number of organic compounds (curare, quaternary salts of bicuculline, dequalinium, $N$-methyl-laudanosine, UCL 1684 and UCL 1848) (Table 1, for reviews see also $[2,7])$. IK channels present a distinct pharmacology [19-21], being insensitive to apamin, but blocked by the scorpion toxins charybdotoxin $\left(\mathrm{IC}_{50}: 2-28 \mathrm{nM}\right.$; Table 2$)$ and maurotoxin $\left(\mathrm{IC}_{50}\right.$ : 0.8-1.4 nM; Table 2). 
Table 1. Pharmacology of recombinantly expressed SK channels.

\begin{tabular}{|c|c|c|c|c|}
\hline \multicolumn{5}{|c|}{ Toxins } \\
\hline Compound & $\mathrm{IC}_{50}$ & $\operatorname{SK} 1\left(\mathrm{~K}_{\mathrm{Ca}} 2.1\right)^{\mathrm{a}}$ & SK2 $\left(\mathrm{K}_{\mathrm{Ca}} 2.2\right)$ & $\mathrm{SK} 3\left(\mathrm{~K}_{\mathrm{Ca}} 2.3\right)$ \\
\hline Apamin & $\mathrm{nM}$ & 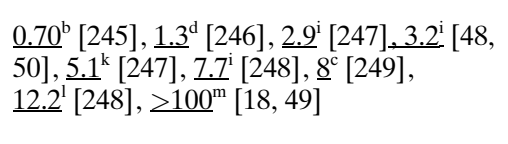 & $\begin{array}{l}0.027[245], 0.03[50], \\
0.063[18], \underline{0.07^{\mathrm{d}}}[246] \\
0.083[247], 0.095[47] \\
\underline{0.14}[249],\end{array}$ & 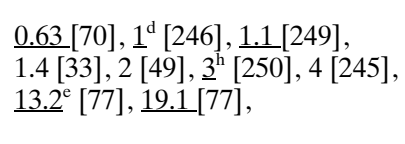 \\
\hline PO5 & $\mathrm{nM}$ & & & $\underline{25}[57]$ \\
\hline $\begin{array}{l}\text { Scyllatoxin } \\
\text { (Leiurotoxin I) }\end{array}$ & $\mathrm{nM}$ & $\underline{80}[247], \underline{325}[57]$ & $0.29[247], 0.3[251]$ & $\underline{1.1}[57], 8.3[33]$ \\
\hline Lei-Dab $7^{\mathrm{f}}$ & $\mathrm{nM}$ & $\underline{6000}[57]$ & $\underline{5.5}[57]$ & $\underline{2500}[57]$ \\
\hline Tamapin & $\mathrm{nM}$ & $\underline{42}[62]$ & $0.024[62]$ & $1.7[62]$ \\
\hline Tsк & $\mathrm{nM}$ & & & $\underline{198}[57]$ \\
\hline \multicolumn{5}{|c|}{ Organic blockers/inhibitors } \\
\hline Compound & $\mathrm{IC}_{50}$ & $\operatorname{SK} 1\left(\mathrm{~K}_{\mathrm{Ca}} 2.1\right)^{\mathrm{a}}$ & SK2 $\left(\mathrm{K}_{\mathrm{Ca}} 2.2\right)$ & $\mathrm{SK} 3\left(\mathrm{~K}_{\mathrm{Ca}} 2.3\right)$ \\
\hline $\begin{array}{l}\text { Quaternary } \\
\text { Bicuculline salts }\end{array}$ & $\mu \mathrm{M}$ & $\underline{1.4}[252], \underline{15.9}[247]$ & $1.1[252], 25[247]$ & $6.6[70]$ \\
\hline Dequalinium & $\mu \mathrm{M}$ & $\underline{0.44}[247], \underline{0.48}[248]$ & 0.16 [247], 0.35 [76] & $\underline{30}^{\mathrm{e}}[77]$ \\
\hline d-Tubocurarine & $\mu \mathrm{M}$ & $\begin{array}{l}\underline{23.5}[248], \underline{27}[247], \underline{30.8}[50], \underline{76.2}[18],\end{array}$ & 2.4 [18], 5.4 [49], 17 [247] & $\underline{210}^{\mathrm{e}}[77]$ \\
\hline UCL 1684 & $\mathrm{nM}$ & $\underline{0.76}[247]$ & $\underline{0.28}[253], 0.36[247]$ & $5.8[33], \underline{9.5}[253]$ \\
\hline UCL 1848 & $\mathrm{nM}$ & $\underline{1.1}[248]$ & 0.11 [47], 0.12 [33], & $2.1[33]$ \\
\hline Calyculin A & $\mathrm{nM}$ & & & $\underline{240}^{\mathrm{e}}[77]$ \\
\hline Okadaic acid & $\mathrm{nM}$ & & & $\underline{506}^{\mathrm{e}}[77]$ \\
\hline Amitriptyline & $\mu \mathrm{M}$ & & $54.8[76]$ & $39[70]$ \\
\hline Carbamazepine & $\mu \mathrm{M}$ & & $14.5[76]$ & \\
\hline Chlorpromazine & $\mu \mathrm{M}$ & & $12.8[76]$ & $0.6[70], \underline{33}^{\mathrm{e}}[77]$ \\
\hline Cyproheptadine & $\mu \mathrm{M}$ & & $15.3[76]$ & $9.2[70]$ \\
\hline Desipramine & $\mu \mathrm{M}$ & & & $\underline{29}^{\mathrm{e}}[77]$ \\
\hline Fluoxetine & $\mu \mathrm{M}$ & $\underline{9}^{\mathrm{e}}[78]$ & $\underline{7^{\mathrm{e}}}[78]$ & $\underline{17}[78], \underline{20^{\mathrm{e}}}[78]$ \\
\hline Fluphenazine & $\mu \mathrm{M}$ & & & $\underline{13}^{\mathrm{e}}[77]$ \\
\hline Imipramine & $\mu \mathrm{M}$ & & $21.7[76]$ & $\underline{44}^{\mathrm{e}}[77]$ \\
\hline Nortriptyline & $\mu \mathrm{M}$ & & & $\underline{20}^{\mathrm{e}}[77]$ \\
\hline Promethazine & $\mu \mathrm{M}$ & & & $\underline{31^{\mathrm{e}}}[77]$ \\
\hline Tacrine & $\mu \mathrm{M}$ & & $53.7[76]$ & \\
\hline Trifluoperazine & $\mu \mathrm{M}$ & & $7.6[76]$ & $\underline{48}^{\mathrm{e}}[77]$ \\
\hline Methyl-laudanosine & $\mu \mathrm{M}$ & $\underline{1.2}[254]$ & $0.8[254]$ & $1.8[254]$ \\
\hline Methyl-noscapine & $\mu \mathrm{M}$ & $\underline{5.9}[254]$ & $5.6[254]$ & $3.9[254]$ \\
\hline NS8593 & $\mu \mathrm{M}$ & $\underline{415}[75]$ & $\underline{598}[75]$ & $\underline{726}[75]$ \\
\hline $\begin{array}{l}\text { 4-Aminopyridine } \\
\text { (4-AP) }\end{array}$ & $\mu \mathrm{M}$ & & & $512[70]$ \\
\hline $\begin{array}{l}\text { Tetraethylammonium } \\
\text { (TEA) }\end{array}$ & $\mathrm{mM}$ & $\underline{5.2}[50], \underline{14.1}[255], \underline{14.6}[49]$ & $2.8[255]$ & $8.7[255]$ \\
\hline \multicolumn{5}{|c|}{ Enhancers } \\
\hline Compound & $\mathrm{EC}_{50}$ & $\operatorname{SK} 1\left(\mathrm{~K}_{\mathrm{Ca}} 2.1\right)^{\mathrm{a}}$ & SK2 $\left(\mathrm{K}_{\mathrm{Ca}} 2.2\right)$ & SK3 $\left(\mathrm{K}_{\mathrm{Ca}} 2.3\right)$ \\
\hline 1-EBIO & $\mu \mathrm{M}$ & $\underline{631}[193]$ & $\frac{453}{996}[72], 654[66], \underline{866}[193]$ & $\frac{87[7], \underline{545}^{\mathrm{h}}}{\underline{1040}[74]}[250], \underline{789}[193,250]$, \\
\hline $\begin{array}{l}\text { Dichloro-EBIO } \\
\text { (DCEBIO) }\end{array}$ & $\mu \mathrm{M}$ & & $\underline{27}[72]$ & $\begin{array}{l}\underline{12}[7], \underline{16}[74], \underline{28}[250], \\
\underline{100}^{\mathrm{h}} \\
{[250],}\end{array}$ \\
\hline NS309 & $\mu \mathrm{M}$ & & $\underline{0.62}[72]$ & $\begin{array}{l}\underline{0.12}[7], \underline{0.30}\left[\underline{1}^{\mathrm{h}}[250],\right.\end{array}$ \\
\hline
\end{tabular}


Table 1 (Continued)

\begin{tabular}{|c|c|c|c|}
\hline \multicolumn{4}{|c|}{ Enhancers } \\
\hline СуРPA & $\mu \mathrm{M} \quad>100$ (inactive [74]) & $\underline{14}[74]$ & $\underline{5.6}[74]$ \\
\hline Riluzole & $\mu \mathrm{M}$ & $43[69]$ & \\
\hline Zoxazolamine & $\mu \mathrm{M}$ & $696[68]$ & \\
\hline Chlorzoxazone & $\mu \mathrm{M}$ & 87 [67], 960 [68] & \\
\hline GW275919X & $\mu \mathrm{M}$ & & $\underline{170}[250], \geq 100^{\mathrm{h}}[250]$ \\
\hline CCI7950 & $\mu \mathrm{M}$ & & $\underline{5}^{\mathrm{h}}[250]$ \\
\hline
\end{tabular}

Reported are $\mathrm{IC}_{50}$ values obtained from electrophysiological recordings, rubidium flux and functional fluorescence assays. Underlined values have been obtained from the human SK channel clones, all other values from the rat SK channel clones.

${ }^{a}$ Rat SK1 (rSK1) subunits do not seem to form functional homomeric channels [46-48]. However, chimeric channel subunits containing the transmembrane domain of rSK1, including the pore region, and intracellular N and C termini or solely C termini of rat SK2 (rSK2) or human SK1 (hSK1), form channels with an $\mathrm{IC}_{50}$ for apamin $>100 \mathrm{nM}$ and for d-tubocurarine $>50 \mu \mathrm{M}$ [48].

${ }^{\mathrm{b}}$ Second component with $\mathrm{IC}_{50}$ of $196 \mathrm{nM}$.

${ }^{\mathrm{c}} \mathrm{Up}$ to $39 \%$ residual current.

${ }^{\mathrm{d}}$ Rubidium flux measurements.

${ }^{\mathrm{e}}$ Fluorescence assays.

${ }^{\mathrm{f}}$ Lei-Dab7: unnatural amino acid diaminobutanotate replacing methionine in Leiurotoxin at position 7 [57]

${ }^{g}$ NS8593 is not a classical blocker, but an inhibitory gating modulator, the first of its kind, that reduces the apparent affinity of the SK channels for $\mathrm{Ca}^{2+}[75]$.

${ }^{\mathrm{h}}$ Results obtained by planar array electrophysiology (population patch [250]).

${ }^{\mathrm{i}}$ Channels expressed in HEK293 cells.

${ }^{\mathrm{k}}$ Channels expressed in $\mathrm{CHO}$ cells.

${ }^{1}$ Channels expressed in COS-7 cells.

${ }^{\mathrm{m}}$ Channels expressed in $X$. laevis oocytes.

Pharmacological tools for the study of SK and IK channel function comprise, beside blockers, positive modulators/enhancers and negative modulators. The prototypical SK channel enhancer is 1-ethyl-2-benzimidazolinone (1-EBIO), first described as acting on native IK channels in colonic epithelial cells [63], and subsequently shown to enhance the activity of recombinant IK channels in transfected cell lines [64, 65]. By increasing the apparent $\mathrm{Ca}^{2+}$ sensitivity of SK channels, 1-EBIO enhances their activity by almost one order of magnitude [66]. Structurally related compounds, such as the muscle relaxants chlorzoxazone and zoxazolamine, similarly enhance the activity of IK and SK2 channels $[67,68]$. The neuroprotective drug riluzole (2-amino-6-trifluoromethoxy benzothiazole), which has some structural resemblance to 1EBIO, similarly enhances the activity of SK2 [69] and SK3 channels [70]. DCEBIO, a dichlorinated analogue of 1-EBIO, enhances the activity of IK channels with a $~ 100$-fold and SK channels with a $\sim 17$-fold higher potency compared to 1-EBIO ([71, 72], and Tables 1 and 2). The most specific and potent positive modulator of IK and SK channels characterized so far is NS309, displaying a potency $~ 7400$-fold (IK channels) and $~ 730$-fold (SK channels) higher than 1EBIO ([72, 73], and Tables 1 and 2). 1-EBIO, DCE$\mathrm{BIO}$ and NS309 all have in common a higher potency on IK compared to SK channels and a relative lack of selectivity for the three SK channel subtypes. A novel positive modulator, CyPPA, has been recently characterized that is more potent than 1-EBIO and
DCEBIO, but less potent than NS309 [74]. However, the most remarkable feature of CyPPA is its selectivity. CyPPA does not affect hIK and hSK1 channels but enhances currents mediated by hSK3 $\left(\mathrm{EC}_{50}=5.6 \mu \mathrm{M}\right)$ and hSK2 $\left(\mathrm{EC}_{50}=14 \mu \mathrm{M}\right)$ channels ([74], and Table 1). While 1-EBIO, DCEBIO, NS309 and CyPPA can be best described as positive gating modulators that increase the apparent $\mathrm{Ca}^{2+}$-sensitivity of SK channels, a recent study has proposed NS8593 to be a negative gating modulator. Negative gating modulation is a novel principle for the selective inhibition of SK channels [75]. NS8593 is chemically different from all known small, organic molecule blockers of SK channels in that it decreases the apparent $\mathrm{Ca}^{2+}$ sensitivity of SK channels by shifting their activation curve by calcium to the right, without affecting their maximal activation [75]. The potency of NS8593 is similar for SK1, SK2 and SK3 channels, while IK channels are not affected ([75], Table 1). Finally, SK channels have been shown to be the targets of a number of neuroactive drugs suppressing channel activity and including tricyclic antidepressants, Prozac: $^{\text {P }}$ (fluoxetine hydrochloride) and anti-psychotic phenothiazines, as summarized in Table 1 [70,76-78]. The availability of this rich collection of pharmacological tools, unprecedented for most other $\mathrm{K}^{+}$ channels, and the recent generation of genetically modified animal models lacking specific SK and IK subunits [79-82] have fostered a number of studies on the function of SK and IK channels in different tissues and brain regions. A number of excellent reviews have 
Table 2. Pharmacology of the cloned IK channel blockers.

\begin{tabular}{|c|c|c|}
\hline Compound & $\mathrm{IC}_{50}$ & $\mathrm{hIK}\left(\mathrm{hK}_{\mathrm{Ca}} 3.1\right)$ \\
\hline Charybdotoxin (CTX) & {$[\mathrm{nM}]$} & $2[19], 2.5[21], 3^{\mathrm{b}}[256], 3.3[257], 10[20], 28[64]$ \\
\hline CTX-Glu ${ }^{32}$ & {$[\mathrm{nM}]$} & $33^{\mathrm{b}}[256]$ \\
\hline Maurotoxin & {$[\mathrm{nM}]$} & $0.81[257], 1.1^{\mathrm{a}}[246], 1.4[246]$ \\
\hline Margatoxin (MgTX) & {$[\mathrm{nM}]$} & $50[7], 459[64],>100[20]$ \\
\hline Orthochirus toxin (OSK1) & {$[\mathrm{nM}]$} & $225[258]$ \\
\hline Stichodactyla toxin (ShK) & {$[\mathrm{nM}]$} & $291[64], 30^{\mathrm{b}}[256,259]$ \\
\hline Bunodosoma toxin $(\mathrm{BgK})$ & {$[\mathrm{nM}]$} & $172[259]$ \\
\hline Clotrimazole & {$[\mathrm{nM}]$} & $24.8[21], 70^{\mathrm{b}}[256], 70-85[260], 153[64], 387[20]$, \\
\hline Econazole & {$[\mu \mathrm{M}]$} & $2.4[64], 10[260], 12^{b}[256]$ \\
\hline Ketoconazole & {$[\mu \mathrm{M}]$} & $30^{\mathrm{b}}[256], 35[260]$ \\
\hline Miconazole & {$[\mu \mathrm{M}]$} & $0.785[64]$ \\
\hline Nifedipine & {$[\mu \mathrm{M}]$} & $4^{\mathrm{b}}[256], 1.5[64]$ \\
\hline Nimodipine & {$[\mu \mathrm{M}]$} & $1^{\mathrm{b}}[256]$ \\
\hline Nitrendipine & {$[\mu \mathrm{M}]$} & $0.9^{\mathrm{b}}[256], 0.027[64]$ \\
\hline Verapamil & {$[\mu \mathrm{M}]$} & $72[64]$ \\
\hline Diltiazem & {$[\mu \mathrm{M}]$} & $154[64]$ \\
\hline Cetiedil & {$[\mu \mathrm{M}]$} & $79[64]$ \\
\hline TEA & {$[\mathrm{mM}]$} & $24^{\mathrm{b}}[256], 30[20]$ \\
\hline Tram- $3^{\mathrm{c}}$ & {$[\mathrm{nM}]$} & $520[260]$ \\
\hline Tram-34 & {$[\mathrm{nM}]$} & $20^{\mathrm{b}}[256,261], 310^{\mathrm{d}}[250]$ \\
\hline Tram-39 & {$[\mathrm{nM}]$} & $60[260]$ \\
\hline Promethazine & {$[\mu \mathrm{M}]$} & $9.3^{\mathrm{e}}[262], 49[262]$ \\
\hline \multicolumn{3}{|c|}{ Enhancers } \\
\hline Compound & $\mathrm{EC}_{50}$ & $\mathrm{hIK}\left(\mathrm{hK}_{\mathrm{Ca}} 3.1\right)$ \\
\hline 1-EBIO & $\mu \mathrm{M}$ & $74[64], 84[67,71], 28.4[66], 67^{\mathrm{d}}[250], 136[193,250]$ \\
\hline Dichloro-EBIO (DCEBIO) & $\mu \mathrm{M}$ & $0.84[71], 2[250], 4^{\mathrm{d}}[250]$ \\
\hline NS309 & $\mathrm{nM}$ & $10[73], 27[7], 30[250], 90^{\mathrm{d}}[250]$ \\
\hline СуPРA & $\mu \mathrm{M}$ & $>10$ (inactive [74]) \\
\hline Chlorzoxazone & $\mu \mathrm{M}$ & 98 [67] \\
\hline GW275919X & $\mu \mathrm{M}$ & $7^{\mathrm{d}}[250]$ \\
\hline CCI7950 & $\mu \mathrm{M}$ & $0.07[250] ; 0.25^{\mathrm{d}}[250]$ \\
\hline
\end{tabular}

Reported are $\mathrm{IC}_{50}$ values obtained from electrophysiological recordings and rubidium flux assays.

${ }^{a}$ Rubidium flux measurements.

${ }^{b}$ amino-terminal GFP-tagged channel was expressed.

c TRAM, triarylmethane.

${ }^{\mathrm{d}}$ Results obtained by planar array electrophysiology (population patch [250]).

${ }^{\mathrm{e}}$ Applied to the in-side of a patch.

recently focused on different aspects of $\mathrm{Ca}^{2+}$-activated $\mathrm{K}^{+}$currents and channels [1-7]. In this review we highlight some recent progress in our understanding of the function of SK and IK channels in selected regions and cell types of the brain.

\section{Small-conductance $\mathrm{Ca}^{2+}$-activated $\mathrm{K}^{+}$channels in central neurons}

\section{SK channel distribution in the limbic system and neocortex}

Pyramidal neurons in the neocortex and in the hippocampal formation display high levels of SK1 and SK2 mRNA $[32,83]$ and protein $[35,36]$, while neurons in the basolateral amygdala express all three SK channel subunits $[32,36]$. The cellular distribution of SK 
channel proteins in the neocortex of adult rat and mouse brain shows SK1 immunoreactivity mainly associated with the neuropil, in particular with fibers extending from layer 5 to layer 1 that might represent the apical dendrites of layer 5 pyramidal neurons [ 35 , 36]. SK 2 immunolabeling is most prominent in the somata and proximal portion of the dendritic tree of layer 5 pyramidal cells, while SK3 displays only a very weak and diffuse immunoreactivity throughout the neocortex [35, 36]. In the hippocampal formation, SK1 immunolabeling is most pronounced in the neuropil of layers CA1-CA3, in particular in the stratum radiatum and, to a slightly lower extent, stratum oriens and lacunosum moleculare, while the pyramidal neuron somata are devoid of signal. Similarly, while the dentate gyrus granule cells show no immunoreactivity at the cell body layer, the mossy fiber system and molecular layer present intense SK1 staining [35, 36]. SK2 immunolabeling is strongest in the CA1-CA2 stratum radiatum and oriens and moderate in the pyramidal cell body layer. In the CA1 stratum radiatum, SK2 has further been shown to be present in dendritic spines, in close proximity to NMDA receptors by double immunogold labeling [84]. Only low level SK2 immunoreactivity is present in the stratum lucidum and dentate gyrus, while high levels have been reported in scattered interneurons in the stratum oriens and radiatum $[35,36]$, in agreement with the presence of SK2 mRNA [85]. SK3 labeling is most prominent in the hilus and in the stratum lucidum of CA3. Staining in the mossy fiber system is punctuate, and moderate staining is associated with the stratum lacunosum moleculare, the strata oriens and radiatum and the molecular layer of the dentate gyrus. SK3 immunoreactivity is very weak to almost absent in the granule and pyramidal cells [35, 36]. However, the expression of SK3 has been reported to increase with age in the hippocampal formation and correlate with age-dependent deficits in synaptic plasticity and hippocampus-dependent learning [86]. Finally, in the amygdala the most prominent immunostaining was observed for SK2 in the lateral and basolateral nuclei. There is only limited information on the cellular distribution of the SK2 protein in these regions, pointing at a somato-dendritic pattern [36].

\section{SK channel function in the neocortex}

In neocortical layer 3-6 pyramidal neurons, an apamin-sensitive $\mathrm{Ca}^{2+}$-activated $\mathrm{K}^{+}$current has been shown to contribute to the generation of the medium duration phase of the afterhyperpolarization (mAHP) that follows single or short bursts of action potentials [87-89]. In these neurons, inhibition of SK channels by apamin leads to a faster steady firing rate and an increased instantaneous firing rate, due to a reduction in the extent of the membrane potential repolarization during the interspike intervals $[87,88]$. The SKmediated mAHP following trains of action potentials results from the activation of voltage-gated $\mathrm{Ca}^{2+}$ channels of the P-type in layer 2-3 neurons, generating elevations of $\left[\mathrm{Ca}^{2+}\right]_{i}$ that cause the opening of SK channels [90]. Additionally, SK channels, activated through muscarinic type 1 or group I metabotropic glutamate receptors and $\mathrm{IP}_{3}$ signaling, mediate slow cholinergic and glutamatergic inhibition of layer 2-3 and 5 pyramidal neurons in several cortical areas [91, 92]. Overexpression of SK1 and SK2 subunits, as well as the application of 1-EBIO, lead to a selective enhancement of the apamin-sensitive $\mathrm{I}_{\mathrm{AHP}}[93,94]$, while this current is strongly reduced in layer 5 pyramidal neurons from transgenic mice expressing a truncated form of the SK3 subunit that acts in a dominant negative fashion and suppresses the expression of all SK and IK channels [94]. These results, together with the observation that rSK1 $\alpha$-subunits seem not to form functional homomeric channels, suggest the presence of heteromeric SK1/SK2 channels in neocortical neurons. However, the actual subunit composition of the SK channels shaping the firing pattern and mediating the cholinergic inhibition of layer 5 neocortical neurons has not been elucidated so far.

\section{SK channel function in the limbic system}

In hippocampal CA1 pyramidal neurons SK 2 seems to be the main SK channel subunit responsible for the generation of the apamin-sensitive afterhyperpolarizing current $\mathrm{I}_{\mathrm{AHP}}$ as supported by pharmacological and in situ hybridization evidence [83], immunohistochemistry [35] and current measurements in mouse neurons lacking the SK1 or SK2 subunit [81]. Two main functions have been described for the SK channels in hippocampal pyramidal neurons. The first is a contribution to the mAHP following bursts of action potentials. Several groups have observed an apamin sensitive component of the mAHP in CA1 pyramidal neurons [83, 95-99], suggesting that SK channels are activated by the opening of voltage-gated calcium channels triggered by action potentials, mediate part of the mAHP, and thereby influence the firing pattern. However, a different result has been reported in one study, which proposed instead that SK channels, although available for activation, are not activated by action potential bursts in CA1 pyramidal cells, and consequently do not affect the mAHP [100]. The reasons for these contrasting results are as yet not clear. The second function of SK channels in hippocampal pyramidal neurons is a consequence of the functional coupling between these channels and NMDA receptors. Exogenous application of NMDA 
or glutamate to hippocampal pyramidal neuron dendrites has been shown to activate SK channels that, in turn, limit the duration of dendritic plateau potentials $[101,102]$. In distal dendritic branches voltage-gated $\mathrm{Ca}^{2+}$ channels can be activated by local photolysis of caged glutamate, resulting in $\mathrm{Ca}^{2+}$ transients whose duration depends on SK channel activity [102]. Beside this action in dendritic segments, SK channels modulate $\mathrm{Ca}^{2+}$ signals at the level of single dendritic spines $[84,103,104]$. Blockade of SK channels by apamin enhances the amplitude of subthreshold glutamatergic excitatory postsynaptic potentials, which is mainly due to the potentiation of the NMDA receptormediated component, resulting in an increased influx of $\mathrm{Ca}^{2+}$ in single dendritic spines [84, 104]. The proposed mechanism in the absence of apamin is that SK channels are activated by $\mathrm{Ca}^{2+}$ entering the spine through NMDA receptors. This causes a local hyperpolarization of the membrane potential that helps to restore the $\mathrm{Mg}^{2+}$ block of the NMDA receptor channels, thereby limiting the amplitude of synaptic potentials and reducing $\mathrm{Ca}^{2+}$ influx through NMDA receptors [104]. Additionally, R-type $\mathrm{Ca}^{2+}$ channels are found selectively on dendritic spines of hippocampal pyramidal neurons and also $\mathrm{Ca}^{2+}$ influx through R-type $\mathrm{Ca}^{2+}$ channels leads also to the activation of SK channels in dendritic spines, resulting in a local dampening of synaptically driven $\mathrm{Ca}^{2+}$ transients and somatic potentials [105]. Given the importance of $\mathrm{Ca}^{2+}$ transients in dendritic spines for the induction of synaptic plasticity [106, 107], these negative feedback systems, where $\mathrm{Ca}^{2+}$ entering the cell activates SK channels, which in turn shut the sources of $\mathrm{Ca}^{2+}$ entry, might explain the role of SK channels and the effects of apamin in lowering the threshold for the induction of long-term potentiation (LTP) and facilitating hippocampus-dependent learning and memory processes [108-111].

In the basolateral amygdala, where both SK2 and SK3 subunits are expressed [32], SK channels activated by somatic depolarizations mediate the mAHP, but do not regulate spike frequency adaptation [112]. Instead, a coupling similar to that described in the hippocampus between SK channels and NMDA receptors has been observed at glutamatergic synapses in pyramidal neurons of the lateral amygdala, where $\mathrm{Ca}^{2+}$ influx through NMDA receptors activates SK channels and shunts the ensuing synaptic potentials [103]. Through this mechanism, SK channels can act as modulators of synaptic plasticity [103], and might ultimately affect amygdala-dependent memory formation and fear conditioning [113].

\section{SK channel modulation}

The central position of the SK channels in the abovedescribed negative feedback systems makes them ideal targets for the neuromodulatory control of intrinsic excitability and synaptic function. However, not much is known about modulation of SK channel activity at the systemic level. At the molecular level, SK channels have been shown to be part of a multiprotein complex comprising casein kinase 2 and protein phosphatase 2A [114, 115]. Casein kinase 2 decreases the sensitivity of SK channels to $\mathrm{Ca}^{2+}$ by phosphorylating calmodulin. This results in a reduction of SK channel activity and a faster deactivation of SK-mediated currents $[114,115]$. Thus, the phosphorylation state of the SK-CaM-CK2-PP2A complex might determine the amplitude and duration of the afterhyperpolarizing potentials shaping the firing patterns of neurons [114, 115]. However, because casein kinase 2 lacks an on-off switch, it is as yet not clear how its activity might be regulated and coordinated with that of protein phosphatase $2 \mathrm{~A}$ in a physiological context.

In layer 5 neocortical pyramidal neurons, the activation of type 5 metabotropic glutamate receptors (mGluR5) leads to a long-lasting reduction of the apamin-sensitive $\mathrm{I}_{\mathrm{AHP}}$ and the $\mathrm{mAHP}$, resulting in the LTP of intrinsic excitability and increased spike timing precision [93]. It will be interesting to see which signal transduction pathways are involved in the modulation of $\mathrm{I}_{\mathrm{AHP}}$ by mGluR5. Further support that SK channels are modulated in a physiological context results from the application of brain-derived neurotrophic factor (BDNF), which inhibits the SK-mediated AHP, possibly by activating serine/threonine protein kinases phosphorylating SK2 channels [96]. The kinase activated by BDNF is not known, but a candidate is protein kinase A (PKA), which can be transiently activated by BDNF signaling in the hippocampus [116]. This is interesting because PKA regulates the surface expression of SK2 channels heterologously expressed in COS7 cells. Here, PKA activation decreases the number of SK2 channels in the plasma membrane, while PKA inhibition has the opposite effect [117]. Taken together, these findings suggest that BDNF might facilitate the induction of LTP by inhibiting SK-mediated currents possibly through the reduction of SK2 surface expression in CA1 pyramidal neurons $[96,117]$. However, to conclusively test this hypothesis the direct effect of BDNF on the $\mathrm{I}_{\mathrm{AHP}}$ and the signal transduction steps leading from BDNF release to the modulation of SK channel activity need to be scrutinized and studied in detail. As for the effect of PKA phosphorylation on SK channels natively expressed in neurons, a recent study has shown that during LTP induction SK2 channels are internalized 
hSK3 MDTSGHFHDSGVGDLDEDPKCPCPSSGDEQQQQQQQQQQQQPPPPAPPAAPQQPLGPSLQPQPPQLQQQQQQQQQQQQQQPPHPLSQLAQLQSQPVHPGL 100

hSK3 LHSSPTAFRAPPSSNSTAILHPSSROGSOLNLNDHLLGHSPSSTATSGPGGGSRHROASPLVHRRDSNPFTEIAMSSCKYSGGVMKPLSRLSASRRNLIE 200 hSK2 -

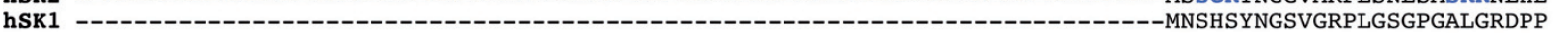

hSK3 AETEGQPLQLFSP-------------------------SNPPEIVISSREDNHAHQTLLHHPNATHNHQHAGTTASSTTFPKANKRKNQNIGYKLGHRRA 275 hSK2 MDSEAQPLQPPASVGGGGGASSPSAAAAAAAAVSSSAPEIVVSKPEHNNSNNLALYGTGGGGSTGGGGGGGGSGHGSSSGTKSSKKKNQNIGYKLGHRRA 126 hSK1 DPEAGHPPQPPHS--- 98

hSK3 LFEKRKRLSDYALIFGMFGIVVMVIETELSWGLYSKDSMFSLALKCLISLSTIILLGLIIAYHTREVQLFVIDNGADDWRIAMTYERILYISLEMLVCAI 375 hSK2 LFEKRKRLSDYALIFGMFGIVVMVIETELSWGAYDKASLYSLALKCLISLSTIILLGLIIVYHAREIQLFMVDNGADDWRIAMTYERIFFICLEILVCAI 226 hSK1 LFEKRKRLSDYALIFGMFGIVVMVTETELSWGVYTKESLYSFALKCLISLSTAILLGLVVLYHAREIQLFMVDNGADDWRIAMTCERVFLISLELAVCAI 198
S1 S1 S3

hSK3 HPIPGEYKFFWTARLAFSYTPSRAEADVDIILSIPMFLRLYLIARVMLLHSKLFTDASSRSIGALNKINFNTRFVMKTLMTICPGTVLLVFSISLWIIAA 475 hSK2 HPIPGNYTFTWTARLAFSYAPSTTTADVDI ILSIPMFLRLYLIARVMLLHSKLFTDASSRSIGALNKINFNTRFVMKTLMTICPGTVLLVFSISLWIIAA 326 hSK1 HPVPGHYRFTWTARLAFTYAPSVAEADVDVLLSIPMFLRLYLLGRVMLLHSKIFTDASSRSIGALNKITFNTRFVMKTLMTICPGTVLLVFSISSWIIAA 298 S4

hSK3 WTVRVCERYHDQQDVTSNFLGAMWLISITFLSIGYGDMVPHTYCGKGVCLLTGIMGAGCTALVVAVVARKLELTKAEKHVHNFMMDTQLTKRIKNAAANV 575 hSK2 WTVRACERYHDQQDVTSNFLGAMWLISITFLSIGYGDMVPNTYCGKGVCLLTGIMGAGCTALVVAVVARKLELTKAEKHVHNFMMDTQLTKRVKNAAANV 426 hSK1 WTVRVCERYHDKQEVTSNFLGAMWLISITFLSIGYGDMVPHTYCGKGVCLLTGIMGAGCTALVVAVVARKLELTKAEKHVHNFMMDTOLTKRVKNAAANV 398 P-Region

hSK3 LRETWLIYKHTKLLKKIDHAKVRKHORKFLOAIHQ---LRSVKMEQRKLSDQANTLVDLSKMONVMYDLITELNDRSEDLEKOIGSLESKLEHLTASFNS 672 hSK2 LRETWLIYKNTKLVKKIDHAKVRKHQRKFLQAIHQ---LRSVKMEQRKLNDQANTLVDLAKTQNIMYDMISDLNERSEDFEKRIVTLETKLETLIGSIHA 523

hSK1 LRETWLIYKHTRLVKKPDQARVRKHQRKFLQAIHQAQKLRSVKIEQGKLNDQANTLTDLAKTQTVMYDLVSELHAQHEELEARLATLESRLDALGASLQA 498 and $\alpha 1^{\prime}$ CaMBD $\alpha 2$ and $\alpha \mathbf{2}^{\prime}$

hSK3 LPLLIADTLRQQQQQLLSAIIEARGVSVAVGTTHTPISDSPIGVSSTSFPTPYTSSSSC

hSK2 LPGLISQTIRQQQRDFIEAQMESYDKHVTYNAERSRSSSRRRRSSSTAPPTSSESS

hSK1 LPGLIAQAIRPPPPPLPPRPGPGPQDQAARSSPCRWTPVAPSDCG

Figure 1. Sequence alignment of the human small conductance $\mathrm{Ca}^{2+}$-activated $\mathrm{K}^{+}$channels hSK1, hSK2 and hSK3. The putative transmembrane spanning regions, S1-S6, are boxed in gray. The pore region (P-Region) is boxed in turquoise. The calmodulin-binding domain (CaMBD) is indicated by black bars. Amino acids corresponding to phosphorylation consensus sequences for the cyclic AMP-and cyclic GMP-dependent kinases (PKA and PKG) are displayed in red, for protein kinase C (PKC) in blue; and for casein kinase 2 (CK2) boxed in orange. Only intracellular phosphorylation consensus sequences have been labeled for PKA, PKG and PKC, while both intra- and extracellular ones have been highlighted for CK2 because of its potential action as an endo- and ectokinase [263]. Phosphorylation consensus sites have been mapped using the Prosite database: for PKA/PKG: PS00004: [RK](2)-x-[ST]; for PKC: PS00005: [ST]-x-[RK]; for CK2: PS00006: [ST]-x(2)-[DE]

from the postsynaptic density into CA1 dendritic spines in a PKA-dependent manner [84]. The reduction in the surface expression of SK2 channels in dendritic spines and consequent potentiation of NMDA-mediated currents, together with the increase in AMPA receptor surface expression, would contribute the synaptic strengthening underlying LTP induction in CA1 neurons [84]. Finally, a recent study showed that sigma-1 receptor activation leads to the inhibition of SK channel activity, resulting in a potentiation of NMDA receptor-mediated currents and LTP in CA1 pyramidal neurons [118]. The mechanism underlying the modulation of neuronal SK channels by sigma receptors remains to be elucidated and will be interesting to study. In conclusion, the presence of multiple consensus phosphorylation sites in the sequences of all three SK channel subunits (Fig. 1), together with the emerging evidence summarized above, suggests that SK channels are important targets for neuromodulatory effects in the brain. The neurotransmitters and signal transduction pathways leading to the modulation of neuronal SK channel activity will be the matter of future studies.

\section{SK channel function in spontaneously active and pacemaking neurons}

SK channel function in dopaminergic neurons. Dopaminergic midbrain neurons express high levels of SK3 mRNA [32, 34, 119] and protein [120]. The emphasis in the research on the role of SK channels in the dopaminergic system is motivated by the impact that subtle changes in the firing patterns of dopaminergic neurons might have on the spatio-temporal profile of dopamine release in different target areas of the brain, which affect motor control functions, working memory, reward and goal-directed behaviors under normal and pathological conditions [121-125]. When recorded in vivo, dopaminergic midbrain neurons display either a single-spike, pacemaking pattern, burst or irregular firing [126-131], while in vitro the main firing pattern observed is a low frequency, singlespike pacemaking activity $[120,127,132-135]$. These spontaneous firing patterns observed in vivo and in vitro result from the concerted activation and complex interaction of a variety of voltage- and ligand-gated ion channels (reviewed by $[122,136])$. In particular, in in vitro recordings from neurons in the substantia nigra pars compacta, SK3 channels are activated by $\mathrm{Ca}^{2+}$ influx through T-type $\mathrm{Ca}^{2+}$ channels and generate a hyperpolarization of the membrane potential resulting in the maintenance of precision and stability 
of the single-spike pacemaker activity of these neurons [137]. Upon activation, SK3 channels stabilize the spontaneous firing frequency of dopaminergic neurons in the low frequency range: at higher frequency, when $\mathrm{Ca}^{2+}$ influx increases, their activation is stronger and leads to slowing down of the firing rate, thereby resulting in a feedback stabilization of the firing frequency [120]. Additionally, SK channels are essential for the maintenance of the temporal precision of the spontaneously occurring action potentials in dopaminergic neurons of the substantia nigra, as revealed by the effect of apamin that reduces spike time precision by blocking SK channels [120]. While some in vitro studies have proposed that SK channel inhibition is per se sufficient to switch the firing mode of dopaminergic neurons from single spiking to bursting [138-141], others have failed to observe burst firing in response to the application of SK channel blockers alone [120,142, 143]. However, the suppression of SK channel activity might favor the transition to a burst firing mode [142, 143], whose occurrence is further facilitated by a concomitant inhibition of T-type $\mathrm{Ca}^{2+}$ channels [137].

In vivo recordings from the substantia nigra and the lateral ventral tegmental area (VTA) have revealed a robust switch from single-spike firing to burst firing upon local application of SK channel blockers [131, 144]. Distinct effects of SK channel inhibitors have been observed in dopaminergic neurons of the VTA in vitro and in vivo. In brain slices containing the medial portion of the VTA, a low level of expression of SK3 channels correlating with a smaller $\mathrm{I}_{\mathrm{AHP}}$ compared to the one observed in the substantia nigra pars compacta, a reduction of spike timing precision and the lack of effect of SK channel blockers on the firing pattern have been observed [120]. The apparent discrepancy between the strong effect of SK channel blockers in vivo and their lack of effect in vitro on the firing pattern of VTA neurons might be due to the presence of a pronounced gradient in the expression of SK3 channel subunits. An increase in mRNA expression has been observed in dopaminergic neurons when going from the medial to the lateral and from the posterior to the anterior portion of the VTA [119].

The inhibition of SK channels in VTA neurons by apamin results in an increase in firing and excitability that is accompanied by an increase in the intracellular $\mathrm{Ca}^{2+}$ concentration leading to the release of endocannabinoids [145]. The endocannabinoids released from the VTA neurons act as retrograde messengers and modulate the release of glutamate and GABA from the presynaptic terminals of afferent fibers innervating the VTA [145]. In this way, SK channels are thought to act as an important component of a feedback system, whereby burst firing of VTA dopaminergic neurons inhibits synaptic inputs and leads to a fine tuning of the firing pattern of these cells, ultimately affecting the timing and amount of dopamine release in areas such as the nucleus accumbens and the prefrontal cortex [145]. In conclusion, SK3 channels, in concert with synaptic signals, render the firing pattern of dopaminergic neurons more precise and control the releases of a retrograde messenger.

SK channel function in the substantia nigra pars reticulata and subthalamic neurons. GABAergic neurons of the substantia nigra pars reticulata (SNR) are a major output system of the basal ganglia. In situ hybridization analysis shows a prevalent presence of SK2 transcript in SNR neurons [32]. Interestingly, at the protein level all three SK subunits are detectable in the SNR [36]. This difference is surprising considering the good agreement of mRNA and protein distribution in other parts of the brain. A detailed study looking at the subcellular distribution and localization of SK in the SNR might provide an explanation. SNR neurons fire spontaneous action potentials and their exposure to apamin leads to a reduction of the AHP following each action potential and a switch from a continuous, single spike discharge mode to a bursting firing pattern [146]. Conversely, application of the SK channel enhancer 1-EBIO leads to an increase in AHP duration, a slowing in the frequency and increased regularity of the discharge of SNR GABAergic neurons, and a prolongation of the silent periods between periods of regular discharge [147]. During action potential discharges, SK channels are activated by calcium coming through voltagegated calcium channels of the T- and N-type in these cells, while release of calcium from intracellular stores does not seem to contribute [146]. However, in juvenile SNR GABAergic neurons, Yanovsky and colleagues $[146,147]$ observed spontaneously occurring, transient outward currents due to the activation of SK channels by sparks of calcium released from ryanodine-sensitive intracellular stores (outward current pulses, OCPs), similar to those previously observed in midbrain dopaminergic neurons (spontaneous, miniature outward currents, SMOCs, [148, 149]). The function of SMOCs/OCPs is still unclear. Neurons of the subthalamic nucleus modulate the activity of the two main output structures of the basal ganglia: the SNR and the internal pallidal segment. Two subunits leading to the formation of channels highly (SK2) or less sensitive (SK3) to apamin are expressed in subthalamic neurons [32, 36]. The presence of both subunits might be the molecular background for the intermediate apamin sensitivity $\left(\mathrm{IC}_{50}=246 \mathrm{pM}\right)$ of the observed AHP current [150]. 
In the subthalamic neurons the SK channels, coupled to $\mathrm{N}$-type $\mathrm{Ca}^{2+}$ channels, regulate the time precision of the intrinsic single-spike firing [150], a type of activity that might be relevant for the subthalamic control of basal ganglia function in vivo [151]. The effect of SK channels on spike timing precision is less prominent at high firing frequencies $(>10 \mathrm{~Hz})$, where calcium accumulates and reaches a concentration that is linearly related to the firing frequency [150]. At high firing frequencies, SK channels mainly influence the frequency of the action potentials rather than their timing [150]. Finally, SK channels contribute to the regulation of the duration and intensity of rebound burst activity in subthalamic neurons. Different from the SK regulation of single-spike firing that depends on the coupling to N-type $\mathrm{Ca}^{2+}$ channels, the action of SK channels on rebound burst activity is due to coupling to T-type $\mathrm{Ca}^{2+}$ channels in subthalamic neurons [150]. This is an interesting example of how the function of SK channels can vary depending on their functional coupling to different $\mathrm{Ca}^{2+}$ sources in the same neuron. Although the functional importance of rebound bursts is not completely understood, bursting of subthalamic neurons has been shown to be associated with pathological conditions, such as Parkinson's disease (see e.g., [152]). Because of their regulation of burst termination and intensity, it might be worthy investigating the role of SK channels in pathologies of the basal ganglia system.

SK channel function in the striatum. Cholinergic interneurons, although representing only $1 \%$ of all striatal neurons, innervate the whole striatum and acetylcholine released by these neurons is responsible for a host of important modulatory effects on neuronal excitability and synaptic transmission. These interneurons are tonically active and their firing pauses during learning of stimulus-reward associations [153, 154]. In the slice preparation, striatal cholinergic interneurons display two main spontaneous firing modes: single spiking and rhythmic bursting. In the single-spiking pattern, action potentials activate an apamin-sensitive, SK-mediated potassium current, $\mathrm{I}_{\mathrm{AHP}}$ underlying an mAHP [155]. The SK-mediated mAHP leads to the activation of a hyperpolarizationactivated cation $\left(\mathrm{HCN}, \mathrm{I}_{\mathrm{h}}\right)$ current, which depolarizes the cells enough to trigger the activation of a persistent sodium current driving the membrane potential towards the action potential threshold [155]. Block of the SK channels favors the transition from the single-spiking to the bursting mode [155]. Rhythmic bursting is instead promoted by a slow, apamininsensitive, calcium-activated potassium current, $\mathrm{sI}_{\mathrm{AHP}}$ that mediates a slow AHP (sAHP) lasting several seconds and terminates bursts or prolonged subthreshold depolarizations [154]. As in other brain regions, the channels underlying $\mathrm{SI}_{\mathrm{AHP}}$ have not yet been identified [3-5]. The calcium-activated potassium channels underlying $\mathrm{I}_{\mathrm{AHP}}$ and $\mathrm{sI}_{\mathrm{AHP}}$ are functionally coupled to different calcium sources in striatal cholinergic interneurons. Thus, while the SK channels are mainly coupled to $\mathrm{N}$-type $\mathrm{Ca}^{2+}$ channels $\left(\mathrm{Ca}_{\mathrm{v}} 2.2\right)$, the sAHP channels are activated by calcium entering through L-type $\mathrm{Ca}^{2+}$ channels $\left(\mathrm{Ca}_{\mathrm{v}} 1\right)$ and released from intracellular stores [156]. In cholinergic interneurons, the amplitude of the mAHP, the level of membrane potential depolarization, and the firing rate are modulated by the activity of $\mathrm{N}$-type $\mathrm{Ca}^{2+}$ channels through their coupling to SK channels [156]. Thus, inhibition of $\mathrm{N}$-type $\mathrm{Ca}^{2+}$ channels leads to a reduction in the SK-mediated $\mathrm{mAHP}$ following action potentials and to burst firing. Under these conditions, further inhibition of the L-type $\mathrm{Ca}^{2+}$ channels or of the release of $\mathrm{Ca}^{2+}$ from intracellular stores reduces the post-burst sAHP, disrupting the burst activity induced by SK current reduction, and favors the single-spiking mode [156]. Thus, the spontaneous activity of striatal cholinergic interneurons and its modulation result from the subtle interplay between $\mathrm{I}_{\mathrm{AHP}}$ and $\mathrm{sI}_{\mathrm{AHP}}$; the balance between these currents and their specific $\mathrm{Ca}^{2+}$ sources is important for the maintenance of striatal function and might be perturbed in pathological conditions such as Parkinson's disease.

SK channel function in the cerebellum. In the cerebellum, SK channels are important players in shaping the firing patterns of Purkinje cells, Golgi cells and neurons of the deep cerebellar nuclei (DCN). In Purkinje cells, the only output neurons in the cerebellar cortex, spike-triggered elevations in intracellular $\mathrm{Ca}^{2+}$ lead to the activation of SK channels mainly of the SK2 type [157]. When the spontaneous firing activity of Purkinje cells is measured at room temperature, blockade of SK channels favors the transition from single-spiking to the burst firing mode [157]. Additionally, inhibition of SK channels leads to a shortening of burst duration, an increase in burst frequency and in the intraburst frequency of action potentials [157]. Conversely, SK channel activity enhancement by 1 -EBIO stabilizes the single-spiking firing mode and increases spike timing precision in these cells [157]. At higher temperatures $\left(33-35^{\circ} \mathrm{C}\right)$, SK channels were shown to contribute to the AHP following single spikes and regulate the firing frequency in both the single-spiking and burst firing modes $[158,159]$. The activation of SK channels in Purkinje cells is selectively linked to $\mathrm{Ca}^{2+}$ influx through $\mathrm{P} / \mathrm{Q}$-type $\mathrm{Ca}^{2+}$ channels $[158,160]$, so that small alterations in $\mathrm{P} / \mathrm{Q}$-type $\mathrm{Ca}^{2+}$ currents can have a strong impact on the firing properties of the Purkinje 
cells through their modulation of SK channel activity [161]. Golgi cells are the main inhibitory neurons of the granular layer in the cerebellum. A recent, elegant study demonstrated the intrinsic pacemaking ability of Golgi cells in slices as a low-frequency, rhythmic firing in the absence of synaptic inputs [162]. Golgi cells express high levels of the SK3 subunit [32]. In these neurons the SK3 channels are activated by $\mathrm{Ca}^{2+}$ influx triggered by single action potentials and mediate an AHP following each spike [162]. Their inhibition by apamin leads to a remarkable change in the spike timing precision of Golgi cells, without affecting the overall spike frequency [162]. Thus, as in other low frequency pacemaker neurons, SK channels are essential for generating highly precise pacemaking in Golgi cells [162].

Finally, pharmacological and genetic approaches have been taken to elucidate the function of SK channels in neurons of the DCN [82,163-165]. These neurons are an important site of integration in the cerebellum, since they receive inhibitory inputs from Purkinje cells in the cerebellar cortex and excitatory inputs from mossy and climbing fibers originating from various precerebellar nuclei and the inferior olive. Integration of these inputs results in the firing of DCN neurons, which in turn project to various premotor centers including the thalamus, red nucleus and superior colliculus. DCN neurons are spontaneously active at rest $[163,166]$. Most DCN neurons fire in a singlespiking mode $[82,163,166]$ : inhibition of SK channels by apamin leads to a reduction in the post-spike AHP and an increase in the tonic firing frequency $[82,163]$. At para-physiological temperatures, SK channel inhibition further favors a transition to a burst-firing mode [163, 165], as observed also in Purkinje cells [157]. Additionally, in DCN neurons SK channels regulate the amplitude and duration of the so-called rebound depolarization, which follows a transient period of hyperpolarization of the membrane potential and is mediated by several current components including T-type $\mathrm{Ca}^{2+}$ current and $\mathrm{I}_{\mathrm{h}}$ [163]. Apamin increases the frequency of the action potentials overriding the rebound depolarization and leads to a prolongation of its duration, frequently resulting in the generation of plateau potentials in DCN neurons [163]. The SK channels responsible for these effects are most likely formed by SK1 and SK2 subunits, while no [32, 82] or only weak [36] SK3 expression was detected in the DCN. The impact of SK channels on the function of DCN neurons has been further corroborated by experiments performed on transgenic mice expressing a dominant negative variant of the SK3 subunit (SK3-1B, [24]) that suppresses the expression of all SK channel subtypes. In transgenic mouse lines, SK3-1B was only detected in DCN neurons within the cerebellum and consequently suppressed all SK-mediated currents in these neurons. The observed enhancement of spontaneous firing frequencies was similar to those observed after application of apamin [82]. Interestingly, the behavioral correlate of this enhanced excitability and spontaneous firing of DCN neurons is a form of ataxia that develops in spite of an intact cerebellar cortical circuitry [82].

\section{Small- and intermediate-conductance $\mathrm{Ca}^{2+}$-activated $\mathrm{K}^{+}$channels in glial cells and cerebral blood vessels}

Although the molecular and functional properties of SK channels have been most extensively characterized in neurons, there is emerging evidence for the expression and function of these channels in glial cells. In particular, SK3 channel expression has been shown by light and electron microscopy in astrocytes of the supraoptic nucleus and, at lower expression levels, of the substantia nigra pars compacta in adult rat and mouse brain [167], and in olfactory ensheathing glial cells [168]. However, the function of SK channels in astrocytes is still unknown. $\mathrm{Ca}^{2+}$ signaling plays a pivotal role in astrocyte function [169], and SK channels might help to maintain long-lasting hyperpolarizations at moderate $\left[\mathrm{Ca}^{2+}\right]_{\mathrm{i}}$ or play a role in the timing and propagation of intercellular $\mathrm{Ca}^{2+}$ waves. Additionally, SK channels are potential targets for the action of neurotransmitters (i.e., serotonin, [170]) and peptides (i.e., endothelin, [171]) acting through the mobilization of intracellular $\mathrm{Ca}^{2+}$ in cultured striatal and cortical astrocytes. Microglial cells, the macrophage-like cells of the CNS, respond to a variety of CNS insults such as microbial invasion, by changing their morphology, rapidly up-regulating a large number of receptor types and producing a variety of secretory products that are thought to contribute to the defense of and, potentially, damage to the infected brain [172]. Activated microglial cells generate socalled "respiratory bursts", leading to the production of superoxide and other reactive oxygen intermediates that have anti-microbial functions but can at the same time damage by-stander cells and cause neurotoxicity. Cultured microglial cells from rat and mouse brain have been shown to express both SK (SK2, SK3) and IK channels [173, 174]. In particular, IK channels play important roles in the membrane hyperpolarization and migration of microglial cells activated by lysophospholipids [174, 175], and in the microglia activation by lipopolysaccharide and consequent nitric oxide-dependent neurotoxic effects [176]. Both SK (most likely SK2) and IK channels play a significant role in the NADPH-mediated respiratory 
burst generated by treating microglia with phorbol esters [173]. These studies suggest that SK and IK channels might be potential therapeutic targets for the prevention of microglia-mediated neurotoxic effects triggered, for example, by inflammatory agents.

Another prominent site of expression of SK and IK channels in the brain is the cerebral vasculature, in which the function of these channels has been investigated. Generally, in blood vessels endothelial cells control the tone of the underlying vascular smooth muscle cells by releasing various relaxing and contracting factors, including nitric oxide (NO) and prostacyclin (PGI2) [177]. Besides NO and PGI2, a third endothelium-dependent vasodilatory process has been described in both cerebral and peripheral circulations, which is dependent on an intact endothelium, extracellular $\mathrm{Ca}^{2+}$, and activation of $\mathrm{Ca}^{2+}$ dependent $\mathrm{K}^{+}$channels and leads to a smooth muscle hyperpolarization and subsequent vasodilatation (reviewed in [177-179]). This process was initially thought to involve production of an endothelial factor, which was termed endothelium-derived hyperpolarizing factor (EDHF, [180]). On the basis of experimental evidence, at least three different mechanisms have been proposed to underlie EDHF-dependent relaxation in various arterial beds (reviewed in [177-179]): (i) the $\mathrm{Ca}^{2+}$-dependent synthesis of a cytochrome $\mathrm{P} 450$ metabolite, which is essential for the subsequent endothelium-dependent relaxation; (ii) $\mathrm{K}^{+}$, released from endothelial cells through $\mathrm{Ca}^{2+}$-dependent $\mathrm{K}^{+}$ channels inducing smooth muscle hyperpolarization by activating inwardly rectifying $\mathrm{K}^{+}$channels or the $\mathrm{Na}^{+}-\mathrm{K}^{+}$-ATPase on vascular smooth muscle cells; and (iii) endothelial cell hyperpolarization, possibly due to the opening of $\mathrm{Ca}^{2+}$-dependent $\mathrm{K}^{+}$channels, transmitted to the vascular smooth muscle via gap junctions. Although the relative contribution of each of these mechanisms and their possible interplay are still somewhat controversial and might depend on the type of blood vessel and stimulation, a considerable consensus has been reached that the initial step of EDHFdependent relaxation is the activation of SK (in particular SK3) and IK channels in the endothelium (reviewed in [177-179]), as supported also by findings in genetically modified mice overexpressing or lacking SK3 [181] or lacking IK channels [182]. Thus, in peripheral vessels, it has been shown that EDHFmediated responses are abolished by the combined inhibition of both SK and IK channels [178] that are expressed exclusively in endothelial cells $[181,183$, 184]. The cerebrovascular circulation has, however, distinctive features when compared with peripheral vascular beds. For example, local increases in $\left[\mathrm{K}^{+}\right]_{0}$ due to high neuronal activity can cause local vasodilation, leading to an increase in local blood flow, a process known as active hyperemia in the brain [179]. In the specific case of the EDHF-dependent blood vessel relaxation, in cerebral vessels it has been shown that inhibition of IK channels alone is sufficient to prevent EDHF-dependent relaxation and hyperpolarization $[185,186]$. A recent study found that while SK2 and SK3 channels are present only in the endothelium, IK channels are expressed both in endothelial and smooth muscle cells of middle cerebral arteries [187]. While SK channels contribute to EDHF-dependent hyperpolarization only when the NO synthesis pathway is intact, IK channels alone are sufficient to mediate hyperpolarization and consequent relaxation in the presence of inhibitors of the NO pathway in middle cerebral arteries [187]. The reasons for this difference in the contribution of SK and IK channels to EDHF-dependent relaxation in cerebral arteries are still unknown. It is, however, clear that $\mathrm{Ca}^{2+}$-dependent $\mathrm{K}^{+}$channels of the SK and IK type are both expressed in cerebral blood vessels and play a significant role in the regulation of local blood flow [185-188].

\section{Small-conductance $\mathrm{Ca}^{2+}$-activated $\mathrm{K}^{+}$channels in neuropathology and psychiatric disorders}

\section{SK channels and epilepsy}

The role of SK channels in the modulation of intrinsic excitability and synaptic strength and plasticity has implications for their possible involvement in neuronal dysfunction, either as part of the causal mechanism or as potential therapeutic targets. Although this line of investigation is still at an early stage, most studies have focused on the role of SK channels in hyperexcitability disorders and in particular in epilepsy models. In genetic studies, only the SK3 channel gene $(K C N N 3)$ was investigated and no associations were found between length variations of two adjacent polymorphic CAG-repeats in the coding region of the channel and susceptibility to common subtypes of idiopathic generalized epilepsy [189]. However, in various in vitro models of epilepsy induced in hippocampal slices or slice cultures, a down-regulation of the SK-mediated $\mathrm{I}_{\mathrm{AHP}}$ paralleled the emergence of epileptiform activity [190], and SK channel inhibitors were shown to shape the duration and increase epileptiform bursting activity in the CA3 region [190, 191]. Conversely, SK channel enhancers (i.e., 1EBIO) led to a cessation of spontaneous oscillatory activity in hyperexcitable neuronal networks [66] and epileptiform activity in hippocampal slices [190, 192, 193]. Based on these results, SK channels have been proposed as potential new targets for the treatment of epilepsy. However, a thorough in vivo study [194] 
including different, commonly used epilepsy models has revealed that 1-EBIO, although effective in increasing seizure threshold and reducing their incidence, displayed significant adverse effects (locomotor impairment in the rotarod test) within the therapeutic dose range. 1-EBIO is the prototypical SK channel enhancer, but several of its features might limit its suitability in in vivo situations, in particular its low potency, marginal effect on $\mathrm{sI}_{\mathrm{AHP}}$ [66], similar affinity for all three SK channel subtypes [193], and high affinity for the peripherally expressed IK channels $[64,66]$. More potent SK channel enhancers, with an improved selectivity, such as NS309, modulate neuronal firing patterns solely by enhancing the SKmediated $\mathrm{I}_{\mathrm{AHP}}$ [72], and might therefore display reduced side effects in vivo. Even more promising are SK channel enhancers displaying selectivity for specific SK channel subtypes, and lack of effect on peripheral IK channels, such as the recently characterized CyPPA [74]. It remains to be shown whether SK channel enhancers with a finely tuned selectivity profile might indeed provide new tools for the treatment of epilepsy with a good therapeutic index.

\section{SK channels and ataxia}

Episodic ataxia type 2 is a rare form of inherited ataxia characterized by attacks of incoordination, vertigo and strong migraines. This condition is linked to mutations and partial loss of function of voltage-gated $\mathrm{Ca}^{2+}$ channels of the P/Q type [195]. P/Q $\mathrm{Ca}^{2+}$ channels are highly expressed in the dendrites and somata of cerebellar Purkinje cells, where they play an important role in setting the regularity and timing of spontaneous action potential firing in concert with SK channels, which are in turn activated by the $\mathrm{Ca}^{2+}$ entering through $\mathrm{P} / \mathrm{Q}$ channels [160]. Reduction in $\mathrm{P} / \mathrm{Q}$ currents caused by selective $\mathrm{P} / \mathrm{Q}$ type $\mathrm{Ca}^{2+}$ channel blockers or mutations found in particular mouse strains leads to a disruption in the pacemaking precision of Purkinje cells $[196,197]$. This can to a large extent be compensated by up-regulating the activity of SK channels with enhancers that increase their $\mathrm{Ca}^{2+}$ sensitivity and spike timing precision, such as 1 -EBIO, in vitro $[157,197]$. In an elegant study, Walter and collaborators [197] addressed the question as to whether the disruption of spike timing precision is responsible for the ataxic phenotype of mice harboring mutations in $\mathrm{P} / \mathrm{Q}$ channels or associated proteins. They locally perfused 1-EBIO in the cerebellum of mutant mice and observed a substantial improvement in their performance in tests of cerebellar-dependent motor coordination, while at the same concentration 1-EBIO did not affect wild-type mice [197]. This impressive result suggests that the regularity and precision of Purkinje cell firing is essential for normal cerebellar function, and even subtle disruptions of this pacemaking activity can lead to ataxia [197, 198]. It also opens the way to include SK channels as potential therapeutic targets for the treatment of episodic ataxia in humans. Additionally, an association has been described between the length of the polyglutamine repeat in the SK3 channel gene and autosomal dominant cerebellar ataxia in a casecontrol study [199], although no causal links could be established and more studies on different patient samples are needed to corroborate this finding and clarify its meaning.

SK channels and disorders of the dopaminergic system The mesocorticolimbic dopamine system, including dopaminergic projections from the ventral midbrain to the frontal cortex and the striatum, plays a major role in controlling voluntary movements, motivated behaviors and reward processing. Pathological changes in this pathway are associated with the etiology of Parkinson's disease, schizophrenia, and drug addiction. In vivo, dopaminergic neurons either fire in regular or irregular single-spike mode or discharge bursts of action potentials [126-131]. During burst firing, dopamine release is increased phasically in striatal [200] and cortical [201] target areas of dopaminergic neurons, whereas tonic release during single-spike activity controls the background of dopamine levels that, among other functions, regulates the intensity of the phasic burst-firing signal [136, 202]. The cellular mechanisms that control the transition between pacemaker and burst firing in dopaminergic neurons comprise a complex interplay between their intrinsic membrane properties and afferent inputs. In particular, SK channels play a pivotal role in controlling the transition from bursting to single-spike firing mode, as explained in SK channel function in dopaminergic neurons above. Changes in the degree and/or pattern of dopamine signaling have been implicated in the pathophysiology of Parkinson's disease and schizophrenia [121, 203-205]; therefore, it is conceivable that the modulation of SK channel activity, preferably by subtype selective SK3 inhibitors or enhancers, might represent a novel therapeutic strategy for the treatment of these diseases. In the case of Parkinson's disease, for example, two possible strategies can be envisaged: the inhibition of SK3 channels to favor burst firing and consequently an enhanced release of dopamine from the residual dopaminergic neurons that might lead to an alleviation of the symptoms (see also [2]); or the blockade of SK3 channels in an early phase of the disease to slow down the degeneration of dopaminergic neurons, as it has been shown that SK channel inhibition, by increasing excitability and 
activity of dopaminergic neurons, facilitates their survival in vitro [206].

\section{Trinucleotide polymorphism in SK3 and psychiatric diseases}

The SK3 gene KCNN3 has been regarded as an attractive candidate for bipolar disorder and schizophrenia because of its role in the modulation of neuronal excitability, its expression in selected regions of the brain (i.e., monoaminergic neurons), and the presence of two stretches of CAG repeats that code for polyglutamine residues in the amino-terminal region of the channel, one of which is polymorphic ranging from 4 to 28 repeats [207]. Additionally, KCNN3 maps to chromosome 1q21 [208], and linkage between schizophrenia and chromosome 1q21-22 has been reported [209], making $K C N N 3$ a potential positional candidate gene for schizophrenia. Chandy and colleagues [210] originally reported that patients with schizophrenia presented a significant excess of larger alleles compared to a control group in a casecontrol association study performed on subjects of French-Alsatian and North American origin. Two further case-control studies [211, 212] were subsequently published and supported these findings. A number of studies supporting or opposing the original hypothesis of a genetic link between the KCNN3 gene and schizophrenia can now be found in the literature. Thus, case-control studies on Serbian [213], Jewish $[214,215]$ and French-German samples [208] provided data supporting a link between long CAG repeats and large allele sizes and schizophrenia. Conversely, a number of case-control [216-222] and family-based studies [222-230] failed to support the finding of an excess transmission of large alleles to schizophrenic patients, in some cases reporting the opposite trend towards excess transmission of smaller alleles [219, 224, 229]. Finally, a rare frameshift mutation has been identified in one schizophrenic patient [231], leading to the expression of a truncated SK3 channel comprising the amino-terminal region but missing the transmembrane domains. This truncated protein was shown to have a nuclear localization and suppress the expression of SK2-mediated currents in Jurkat cells [232]. However, in spite of an extensive analysis of subjects with schizophrenia or schizophrenia spectrum disorders, no further individuals carrying this frameshift mutation could be identified [231]. In their original study, Chandy and colleagues [210] suggested also a trend, although not significant, towards the transmission of large $K C N N 3$ allele sizes in bipolar disorder. Subsequent studies failed to support this hypothesis [233-238]. More recently, a meta-analysis based on both case-control and family-based studies on the involvement of $K C N N 3$ in schizophrenia and bipolar disorders has reached the conclusion that the risks for both disorders "are largely, if not entirely, independent of CAG-repeat length in exon 1 of KCNN3“" [239].

The same factors that prompted the investigations on the possible genetic links between KCNN3 and schizophrenia or bipolar disorder (physiological role of SK3 in neurons, expression pattern of SK3 in brain, polymorphic CAG-repeats in the SK3 amino-terminal region and chromosomal localization of the SK3 gene; see above) led also to studies on its possible involvement in anorexia. A series of family-based and casecontrol studies on different ethnic groups in the Israeli Jewish population have shown that KCNN3 alleles with longer CAG-repeats are over-represented among anorexic patients, suggesting that $K C N N 3$ might be a significant contributor to predisposition to anorexia [240-242]. These studies await confirmation from other ethnic backgrounds or family samples.

Finally, two studies have presented contrasting results on the possible genetic link between $K C N N 3$ polymorphisms in the CAG-repeat regions and migraine. In one study on patients recruited from a German headache clinic, an increased frequency of a rare allele comprising 15 CAG-repeats in the second, highly polymorphic stretch of polyglutamines in SK3 was found in migraine patients [243], whereas in the other study on subjects of Caucasian origin no significant association between $K C N N 3$ allelic frequencies of migraine and non-migraine patients was found [244]. In conclusion, although there is no unequivocal evidence for a direct involvement of SK channels in the pathogenesis of CNS disorders, the increasing understanding of their functional role at the cellular and network level, together with the development of novel pharmacological tools for the fine modulation of their activity, have led to novel hypotheses on their potential role as therapeutic targets that are worth exploring.

Acknowledgements. We are grateful to members of our groups and collaborators with whom we have worked on calcium-activated potassium channels over the years. P. P. acknowledges support from the Medical Research Council (Career Establishment Grant), and M. S. from the Wellcome Trust (Senior Research Fellowship).

Open Access This article is distributed under the terms of the Creative Commons Attribution Noncommercial License which permits any noncommercial use, distribution, and reproduction in any medium, provided the orginal author(s) and source are credited.

1 Sah, P. and Faber, E. S. (2002) Channels underlying neuronal calcium-activated potassium currents. Prog. Neurobiol. 66, $345-353$.

2 Liegeois, J. F., Mercier, F., Graulich, A., Graulich-Lorge, F., Scuvee-Moreau, J. and Seutin, V. (2003) Modulation of small 
conductance calcium-activated potassium (SK) channels: A new challenge in medicinal chemistry. Curr. Med. Chem. 10, 625-647.

3 Vogalis, F., Storm, J. F. and Lancaster, B. (2003) SK channels and the varieties of slow after-hyperpolarizations in neurons. Eur. J. Neurosci. 18, 3155-3166.

4 Stocker, M. (2004) $\mathrm{Ca}^{2+}$-activated $\mathrm{K}^{+}$channels: Molecular determinants and function of the SK family. Nat. Rev. Neurosci. 5, 758-770.

5 Stocker, M., Hirzel, K., D’hoedt, D. and Pedarzani, P. (2004) Matching molecules to function: Neuronal $\mathrm{Ca}^{2+}$-activated $\mathrm{K}^{+}$ channels and afterhyperpolarizations. Toxicon 43, 933-949.

6 Bond, C. T., Maylie, J. and Adelman, J. P. (2005) SK channels in excitability, pacemaking and synaptic integration. Curr. Opin. Neurobiol. 15, 305-311.

7 Wulff, H., Kolski-Andreaco, A., Sankaranarayanan, A., Sabatier, J. M. and Shakkottai, V. G. (2007) Modulators of small- and intermediate-conductance calcium-activated potassium channels and their therapeutic indications. Curr. Med. Chem. 14, 1437-1457.

8 Marty, A. (1981) Ca-dependent K channels with large unitary conductance in chromaffin cell membranes. Nature 291, 497500.

9 Pallotta, B. S., Magleby, K. L. and Barrett, J. N. (1981) Single channel recordings of $\mathrm{Ca}^{2+}$-activated $\mathrm{K}^{+}$currents in rat muscle cell culture. Nature 293, 471-474.

10 Kaczorowski, G. J., Knaus, H. G., Leonard, R. J., McManus, O. B. and Garcia, M. L. (1996) High-conductance calciumactivated potassium channels; structure, pharmacology, and function. J. Bioenerg. Biomembr. 28, 255-267.

11 Calderone, V. (2002) Large-conductance, $\mathrm{Ca}^{2+}$-activated $\mathrm{K}^{+}$ channels: Function, pharmacology and drugs. Curr. Med. Chem. 9, 1385-1395.

12 Fury, M., Marx, S. O. and Marks, A. R. (2002) Molecular BKology: The study of splicing and dicing. Sci. STKE 2002, pe12.

13 Orio, P., Rojas, P., Ferreira, G. and Latorre, R. (2002) New disguises for an old channel: MaxiK channel beta-subunits. News Physiol. Sci. 17, 156-161.

14 Rothberg, B. S. (2004) Allosteric modulation of ion channels : The case of maxi-K. Sci. STKE 2004, pe16.

15 Ghatta, S., Nimmagadda, D., Xu, X. and O'Rourke, S. T. (2006) Large-conductance, calcium-activated potassium channels: Structural and functional implications. Pharmacol. Ther. 110, 103-116.

16 Latorre, R. and Brauchi, S. (2006) Large conductance $\mathrm{Ca}^{2+}$ activated $\mathrm{K}^{+}(\mathrm{BK})$ channel: Activation by $\mathrm{Ca}^{2+}$ and voltage. Biol. Res. 39, 385-401.

17 Salkoff, L., Butler, A., Ferreira, G., Santi, C. and Wei, A. (2006) High-conductance potassium channels of the SLO family. Nat. Rev. Neurosci. 7, 921-931.

18 Kohler, M., Hirschberg, B., Bond, C. T., Kinzie, J. M. Marrion, N. V., Maylie, J. and Adelman, J. P. (1996) Smallconductance, calcium-activated potassium channels from mammalian brain. Science 273, 1709-1714.

19 Joiner, W. J., Wang, L. Y., Tang, M. D. and Kaczmarek, L. K. (1997) hSK4, a member of a novel subfamily of calciumactivated potassium channels. Proc. Natl. Acad. Sci. USA 94, 11013-11018.

20 Logsdon, N. J., Kang, J., Togo, J. A., Christian, E. P. and Aiyar, J. (1997) A novel gene, hKCa4, encodes the calcium-activated potassium channel in human $\mathrm{T}$ lymphocytes. J. Biol. Chem. 272, 32723-32726.

21 Ishii, T. M., Silvia, C., Hirschberg, B., Bond, C. T., Adelman, J P. and Maylie, J. (1997) A human intermediate conductance calcium-activated potassium channel. Proc. Natl. Acad. Sci. USA 94, 11651-11656.

22 Shmukler, B. E., Bond, C. T., Wilhelm, S., Bruening-Wright, A., Maylie, J., Adelman, J. P. and Alper, S. L. (2001) Structure and complex transcription pattern of the mouse SK1 $\mathrm{K}_{\mathrm{C}}$ channel gene, KCNN1. Biochim. Biophys. Acta 1518, 36-46.
23 Strassmaier, T., Bond, C. T., Sailer, C. A., Knaus, H. G., Maylie, J. and Adelman, J. P. (2005) A novel isoform of SK2 assembles with other SK subunits in mouse brain. J. Biol. Chem. 280, 21231-21236.

24 Tomita, H., Shakkottai, V. G., Gutman, G. A., Sun, G., Bunney, W. E., Cahalan, M. D., Chandy, K. G. and Gargus, J. J. (2003) Novel truncated isoform of SK3 potassium channel is a potent dominant-negative regulator of SK currents: Implications in schizophrenia. Mol. Psychiatry 8, 524-535.

25 Wittekindt, O. H., Visan, V., Tomita, H., Imtiaz, F., Gargus, J. J., Lehmann-Horn, F., Grissmer, S. and Morris-Rosendahl, D. J. (2004) An apamin- and scyllatoxin-insensitive isoform of the human SK3 channel. Mol. Pharmacol. 65, 788-801.

26 Xia, X. M., Fakler, B., Rivard, A., Wayman, G., Johnson-Pais, T., Keen, J. E., Ishii, T., Hirschberg, B., Bond, C. T., Lutsenko, S., Maylie, J. and Adelman, J. P. (1998) Mechanism of calcium gating in small-conductance calcium-activated potassium channels. Nature 395, 503-507.

27 Hirschberg, B., Maylie, J., Adelman, J. P. and Marrion, N. V. (1998) Gating of recombinant small-conductance Ca-activated $\mathrm{K}^{+}$channels by calcium. J. Gen. Physiol. 111, 565-581.

28 Fanger, C. M., Ghanshani, S., Logsdon, N. J., Rauer, H., Kalman, K., Zhou, J., Beckingham, K., Chandy, K. G., Cahalan, M. D. and Aiyar, J. (1999) Calmodulin mediates calcium-dependent activation of the intermediate conductance $\mathrm{K}_{\mathrm{Ca}}$ channel, IKCa1. J. Biol. Chem. 274, 5746-5754.

29 Keen, J. E., Khawaled, R., Farrens, D. L., Neelands, T., Rivard, A., Bond, C. T., Janowsky, A., Fakler, B., Adelman, J. P. and Maylie, J. (1999) Domains responsible for constitutive and $\mathrm{Ca}^{2+}$-dependent interactions between calmodulin and small conductance $\mathrm{Ca}^{2+}$-activated potassium channels. J. Neurosci. $19,8830-8838$.

30 Schumacher, M. A., Rivard, A. F., Bachinger, H. P. and Adelman, J. P. (2001) Structure of the gating domain of a $\mathrm{Ca}^{2+}$ activated $\mathrm{K}^{+}$channel complexed with $\mathrm{Ca}^{2+} /$ calmodulin. Nature 410, 1120-1124.

31 Rimini, R., Rimland, J. M. and Terstappen, G. C. (2000) Quantitative expression analysis of the small conductance calcium-activated potassium channels, SK1, SK2 and SK3, in human brain. Brain Res. Mol. Brain Res. 85, 218-220.

32 Stocker, M. and Pedarzani, P. (2000) Differential distribution of three $\mathrm{Ca}^{2+}$-activated $\mathrm{K}^{+}$channel subunits, SK1, SK2, and SK3, in the adult rat central nervous system. Mol. Cell. Neurosci. 15, 476-493.

33 Hosseini, R., Benton, D. C., Dunn, P. M., Jenkinson, D. H. and Moss, G. W. (2001) SK3 is an important component of $\mathrm{K}^{+}$ channels mediating the afterhyperpolarization in cultured rat SCG neurones. J. Physiol. 535, 323-334.

34 Tacconi, S., Carletti, R., Bunnemann, B., Plumpton, C., Merlo Pich, E. and Terstappen, G. C. (2001) Distribution of the messenger RNA for the small conductance calcium-activated potassium channel SK3 in the adult rat brain and correlation with immunoreactivity. Neuroscience 102, 209-215.

35 Sailer, C. A., Hu, H., Kaufmann, W. A., Trieb, M., Schwarzer, C., Storm, J. F. and Knaus, H. G. (2002) Regional differences in distribution and functional expression of small-conductance $\mathrm{Ca}^{2+}$-activated $\mathrm{K}^{+}$channels in rat brain. J. Neurosci. 22 , 9698-9707.

36 Sailer, C. A., Kaufmann, W. A., Marksteiner, J. and Knaus, H. G. (2004) Comparative immunohistochemical distribution of three small-conductance $\mathrm{Ca}^{2+}$-activated potassium channel subunits, SK1, SK2, and SK3 in mouse brain. Mol. Cell. Neurosci. 26, 458-469.

37 Bahia, P. K., Suzuki, R., Benton, D. C., Jowett, A. J., Chen, M. X., Trezise, D. J., Dickenson, A. H. and Moss, G. W. (2005) A functional role for small-conductance calcium-activated potassium channels in sensory pathways including nociceptive processes. J. Neurosci. 25, 3489-3498.

38 Mongan, L. C., Hill, M. J., Chen, M. X., Tate, S. N., Collins, S. D., Buckby, L. and Grubb, B. D. (2005) The distribution of small and intermediate conductance calcium-activated potas- 
sium channels in the rat sensory nervous system. Neuroscience 131, 161-175.

39 Thompson-Vest, N., Shimizu, Y., Hunne, B. and Furness, J. B. (2006) The distribution of intermediate-conductance, calcium-activated, potassium (IK) channels in epithelial cells. J. Anat. 208, 219-229.

40 Boettger, M. K., Till, S., Chen, M. X., Anand, U., Otto, W. R., Plumpton, C., Trezise, D. J., Tate, S. N., Bountra, C., Coward, K., Birch, R. and Anand, P. (2002) Calcium-activated potassium channel SK1- and IK1-like immunoreactivity in injured human sensory neurones and its regulation by neurotrophic factors. Brain 125, 252-263.

41 Furness, J. B., Robbins, H. L., Selmer, I. S., Hunne, B., Chen, M. X., Hicks, G. A., Moore, S. and Neylon, C. B. (2003) Expression of intermediate conductance potassium channel immunoreactivity in neurons and epithelial cells of the rat gastrointestinal tract. Cell Tissue Res. 314, 179-189.

42 Furness, J. B., Kearney, K., Robbins, H. L., Hunne, B., Selmer, I. S., Neylon, C. B., Chen, M. X. and Tjandra, J. J. (2004) Intermediate conductance potassium (IK) channels occur in human enteric neurons. Auton. Neurosci. 112, 93-97.

43 Neylon, C. B., Nurgali, K., Hunne, B., Robbins, H. L., Moore, S., Chen, M. X. and Furness, J. B. (2004) Intermediateconductance calcium-activated potassium channels in enteric neurones of the mouse: Pharmacological, molecular and immunochemical evidence for their role in mediating the slow afterhyperpolarization. J. Neurochem. 90, 1414-1422.

44 Roncarati, R., Di Chio, M., Sava, A., Terstappen, G. C. and Fumagalli, G. (2001) Presynaptic localization of the small conductance calcium-activated potassium channel SK3 at the neuromuscular junction. Neuroscience 104, 253-262.

45 Obermair, G. J., Kaufmann, W. A., Knaus, H. G. and Flucher, B. E. (2003) The small conductance $\mathrm{Ca}^{2+}$-activated $\mathrm{K}^{+}$ channel SK3 is localized in nerve terminals of excitatory synapses of cultured mouse hippocampal neurons. Eur. J. Neurosci. 17, 721-731.

46 Bowden, S. E., Fletcher, S., Loane, D. J. and Marrion, N. V. (2001) Somatic colocalization of rat SK1 and D class $\left(\mathrm{Ca}_{\mathrm{v}} 1.2\right)$ L-type calcium channels in rat CA1 hippocampal pyramidal neurons. J. Neurosci. 21, RC175.

47 Benton, D. C., Monaghan, A. S., Hosseini, R., Bahia, P. K., Haylett, D. G. and Moss, G. W. (2003) Small conductance $\mathrm{Ca}^{2+}$-activated $\mathrm{K}^{+}$channels formed by the expression of rat SK1 and SK2 genes in HEK 293 cells. J. Physiol. 553, 13-19.

48 D'hoedt, D., Hirzel, K., Pedarzani, P. and Stocker, M. (2004) Domain analysis of the calcium-activated potassium channel SK1 from rat brain. Functional expression and toxin sensitivity. J. Biol. Chem. 279, 12088-12092.

49 Ishii, T. M., Maylie, J. and Adelman, J. P. (1997) Determinants of apamin and d-tubocurarine block in SK potassium channels. J. Biol. Chem. 272, 23195-23200.

50 Nolting, A., Ferraro, T., D'hoedt, D. and Stocker, M. (2007) An amino acid outside the pore region influences apamin sensitivity in small conductance $\mathrm{Ca}^{2+}$-activated $\mathrm{K}^{+}$channels. J. Biol. Chem. 282, 3478-3486.

51 Kharrat, R., Mabrouk, K., Crest, M., Darbon, H., Oughideni, R., Martin-Eauclaire, M. F., Jacquet, G., el Ayeb, M., Van Rietschoten, J., Rochat, H. and Sabatier, J. M. (1996) Chemical synthesis and characterization of maurotoxin, a short scorpion toxin with four disulfide bridges that acts on $\mathrm{K}^{+}$ channels. Eur. J. Biochem. 242, 491-498.

52 Legros, C., Oughuideni, R., Darbon, H., Rochat, H., Bougis, P. E. and Martin-Eauclaire, M. F. (1996) Characterization of a new peptide from Tityus serrulatus scorpion venom which is a ligand of the apamin-binding site. FEBS Lett. 390, 81-84.

53 Zerrouk, H., Laraba-Djebari, F., Fremont, V., Meki, A. Darbon, H., Mansuelle, P., Oughideni, R., van Rietschoten, J., Rochat, H. and Martin-Eauclaire, M. F. (1996) Characterization of PO1, a new peptide ligand of the apamin-sensitive $\mathrm{Ca}^{2+}$ activated $\mathrm{K}^{+}$channel. Int. J. Pept. Protein Res. 48, 514521.
54 Blanc, E., Lecomte, C., Rietschoten, J. V., Sabatier, J. M. and Darbon, H. (1997) Solution structure of TsKapa, a charybdotoxin-like scorpion toxin from Tityus serrulatus with high affinity for apamin-sensitive $\mathrm{Ca}^{2+}$-activated $\mathrm{K}^{+}$channels. Proteins 29, 359-369.

55 Lecomte, C., Ferrat, G., Fajloun, Z., Van Rietschoten, J., Rochat, H., Martin-Eauclaire, M. F., Darbon, H. and Sabatier, J. M. (1999) Chemical synthesis and structureactivity relationships of Ts kappa, a novel scorpion toxin acting on apamin-sensitive SK channel. J. Pept. Res. 54, 369376.

56 Fajloun, Z., Carlier, E., Lecomte, C., Geib, S., Di Luccio, E., Bichet, D., Mabrouk, K., Rochat, H., De Waard, M. and Sabatier, J. M. (2000) Chemical synthesis and characterization of Pi1, a scorpion toxin from Pandinus imperator active on $\mathrm{K}^{+}$ channels. Eur. J. Biochem. 267, 5149-5155.

57 Shakkottai, V. G., Regaya, I., Wulff, H., Fajloun, Z., Tomita, H., Fathallah, M., Cahalan, M. D., Gargus, J. J., Sabatier, J. M. and Chandy, K. G. (2001) Design and characterization of a highly selective peptide inhibitor of the small conductance calcium-activated $\mathrm{K}^{+}$channel, SkCa2. J. Biol. Chem. 276, 43145-43151.

58 Castle, N. A. and Strong, P. N. (1986) Identification of two toxins from scorpion (Leiurus quinquestriatus) venom which block distinct classes of calcium-activated potassium channel. FEBS Lett. 209, 117-121.

59 Chicchi, G. G., Gimenez Gallego, G., Ber, E., Garcia, M. L., Winquist, R. and Cascieri, M. A. (1988) Purification and characterization of a unique potent inhibitor of apamin binding from Leiurus-Quinquestriatus-Hebraeus venom. J. Biol. Chem. 263, 10192-10197.

60 Auguste, P., Hugues, M., Grave, B., Gesquiere, J. C., Maes, P., Tartar, A., Romey, G., Schweitz, H. and Lazdunski, M. (1990) Leiurotoxin I (scyllatoxin), a peptide ligand for $\mathrm{Ca}^{2+}$-activated $\mathrm{K}^{+}$channels. Chemical synthesis, radiolabeling, and receptor characterization. J. Biol. Chem. 265, 4753-4759.

61 Zerrouk, H., Mansuelle, P., Benslimane, A., Rochat, H. and Martin-Eauclaire, M. F. (1993) Characterization of a new leiurotoxin I-like scorpion toxin. PO5 from Androctonus mauretanicus mauretanicus. FEBS Lett. 320, 189-192.

62 Pedarzani, P., D'Hoedt, D., Doorty, K. B., Wadsworth, J. D., Joseph, J. S., Jeyaseelan, K., Kini, R. M., Gadre, S. V., Sapatnekar, S. M., Stocker, M. and Strong, P. N. (2002) Tamapin, a venom peptide from the Indian red scorpion (Mesobuthus tamulus) that targets small conductance $\mathrm{Ca}^{2+}$ activated $\mathrm{K}^{+}$channels and afterhyperpolarization currents in central neurons. J. Biol. Chem. 277, 46101-46109.

63 Devor, D. C., Singh, A. K., Frizzell, R. A. and Bridges, R. J. (1996) Modulation of $\mathrm{Cl}^{-}$secretion by benzimidazolones. I. Direct activation of a $\mathrm{Ca}^{2+}$-dependent $\mathrm{K}^{+}$channel. Am. J. Physiol. 271, L775-784.

64 Jensen, B. S., Strobaek, D., Christophersen, P., Jorgensen, T. D., Hansen, C., Silahtaroglu, A., Olesen, S. P. and Ahring, P. K. (1998) Characterization of the cloned human intermediate-conductance $\mathrm{Ca}^{2+}$-activated $\mathrm{K}^{+}$channel. Am. J. Physiol. 275, C848-856.

65 Pedersen, K. A., Schroder, R. L., Skaaning-Jensen, B., Strobaek, D., Olesen, S. P. and Christophersen, P. (1999) Activation of the human intermediate-conductance $\mathrm{Ca}^{2+}$ activated $\mathrm{K}^{+}$channel by 1-ethyl-2-benzimidazolinone is strongly $\mathrm{Ca}^{2+}$-dependent. Biochim. Biophys. Acta 1420, 231-240.

66 Pedarzani, P., Mosbacher, J., Rivard, A., Cingolani, L. A., Oliver, D., Stocker, M., Adelman, J. P. and Fakler, B. (2001) Control of electrical activity in central neurons by modulating the gating of small conductance $\mathrm{Ca}^{2+}$-activated $\mathrm{K}^{+}$channels. J. Biol. Chem. 276, 9762-9769.

67 Syme, C. A., Gerlach, A. C., Singh, A. K. and Devor, D. C. (2000) Pharmacological activation of cloned intermediateand small-conductance $\mathrm{Ca}^{2+}$-activated $\mathrm{K}^{+}$channels. Am. J. Physiol. Cell Physiol. 278, C570-581. 
68 Cao, Y., Dreixler, J. C., Roizen, J. D., Roberts, M. T. and Houamed, K. M. (2001) Modulation of recombinant smallconductance $\mathrm{Ca}^{2+}$-activated $\mathrm{K}^{+}$channels by the muscle relaxant chlorzoxazone and structurally related compounds. J. Pharmacol. Exp. Ther. 296, 683-689.

69 Cao, Y. J., Dreixler, J. C., Couey, J. J. and Houamed, K. M. (2002) Modulation of recombinant and native neuronal SK channels by the neuroprotective drug riluzole. Eur. J. Pharmacol. 449, 47-54.

70 Grunnet, M., Jespersen, T., Angelo, K., Frokjaer-Jensen, C. Klaerke, D. A., Olesen, S. P. and Jensen, B. S. (2001) Pharmacological modulation of SK3 channels. Neuropharmacology 40, 879-887.

71 Singh, S., Syme, C. A., Singh, A. K., Devor, D. C. and Bridges, R. J. (2001) Benzimidazolone activators of chloride secretion: Potential therapeutics for cystic fibrosis and chronic obstructive pulmonary disease. J. Pharmacol. Exp. Ther. 296, 600611.

72 Pedarzani, P., McCutcheon, J. E., Rogge, G., Jensen, B. S. Christophersen, P., Hougaard, C., Strobaek, D. and Stocker, M. (2005) Specific enhancement of SK channel activity selectively potentiates the afterhyperpolarizing current $\mathrm{I}_{\mathrm{AHP}}$ and modulates the firing properties of hippocampal pyramidal neurons. J. Biol. Chem. 280, 41404-41411.

73 Strobaek, D., Teuber, L., Jorgensen, T. D., Ahring, P. K. Kjaer, K., Hansen, R. S., Olesen, S. P., Christophersen, P. and Skaaning-Jensen, B. (2004) Activation of human IK and SK $\mathrm{Ca}^{2+}$-activated $\mathrm{K}^{+}$channels by NS309 (6,7-dichloro-1Hindole-2,3-dione 3-oxime). Biochim. Biophys. Acta 1665, 1-5.

74 Hougaard, C., Eriksen, B. L., Jørgensen, S., Johansen, T. H. Dyhring, T., Madsen, L. S., Strøbaek, D. and Christophersen, P. (2007) Selective positive modulation of the SK3 and SK2 subtypes of small conductance $\mathrm{Ca}^{2+}$-activated $\mathrm{K}^{+}$channels. Br. J. Pharmacol. 151, 655-665.

75 Strobaek, D., Hougaard, C., Johansen, T. H., Sorensen, U. S. Nielsen, E. O., Nielsen, K. S., Taylor, R. D., Pedarzani, P. and Christophersen, P. (2006) Inhibitory gating modulation of small conductance $\mathrm{Ca}^{2+}$-activated $\mathrm{K}^{+}$channels by the synthetic compound (R)- $N$-(benzimidazol-2-yl)-1,2,3,4-tetrahydro-1-naphtylamine (NS8593) reduces afterhyperpolarizing current in hippocampal CA1 neurons. Mol. Pharmacol. 70 $1771-1782$.

76 Dreixler, J. C., Bian, J., Cao, Y., Roberts, M. T., Roizen, J. D and Houamed, K. M. (2000) Block of rat brain recombinant SK channels by tricyclic antidepressants and related compounds. Eur. J. Pharmacol. 401, 1-7.

77 Terstappen, G. C., Pula, G., Carignani, C., Chen, M. X. and Roncarati, R. (2001) Pharmacological characterisation of the human small conductance calcium- activated potassium channel hSK3 reveals sensitivity to tricyclic antidepressants and antipsychotic phenothiazines. Neuropharmacology 40 $772-783$.

78 Terstappen, G. C., Pellacani, A., Aldegheri, L., Graziani, F., Carignani, C., Pula, G. and Virginio, C. (2003) The antidepressant fluoxetine blocks the human small conductance calcium-activated potassium channels SK1, SK2 and SK3. Neurosci. Lett. 346, 85-88

79 Bond, C. T., Sprengel, R., Bissonnette, J. M., Kaufmann, W A., Pribnow, D., Neelands, T., Storck, T., Baetscher, M. Jerecic, J., Maylie, J., Knaus, H. G., Seeburg, P. H. and Adelman, J. P. (2000) Respiration and parturition affected by conditional overexpression of the $\mathrm{Ca}^{2+}$-activated $\mathrm{K}^{+}$channel subunit, SK3. Science 289, 1942-1946.

80 Begenisich, T., Nakamoto, T., Ovitt, C. E., Nehrke, K., Brugnara, C., Alper, S. L. and Melvin, J. E. (2004) Physiological roles of the intermediate conductance, $\mathrm{Ca}^{2+}$-activated potassium channel Kcnn4. J. Biol. Chem. 279, 47681-47687.

81 Bond, C. T., Herson, P. S., Strassmaier, T., Hammond, R., Stackman, R., Maylie, J. and Adelman, J. P. (2004) Small conductance $\mathrm{Ca}^{2+}$-activated $\mathrm{K}^{+}$channel knock-out mice reveal the identity of calcium-dependent afterhyperpolarization currents. J. Neurosci. 24, 5301-5306.
82 Shakkottai, V. G., Chou, C. H., Oddo, S., Sailer, C. A., Knaus, H. G., Gutman, G. A., Barish, M. E., LaFerla, F. M. and Chandy, K. G. (2004) Enhanced neuronal excitability in the absence of neurodegeneration induces cerebellar ataxia. J. Clin. Invest. 113, 582-590.

83 Stocker, M., Krause, M. and Pedarzani, P. (1999) An apaminsensitive $\mathrm{Ca}^{2+}$-activated $\mathrm{K}^{+}$current in hippocampal pyramidal neurons. Proc. Natl. Acad. Sci. USA 96, 4662-4667.

84 Lin, M. T., Lujan, R., Watanabe, M., Adelman, J. P. and Maylie, J. (2008) SK2 channel plasticity contributes to LTP at Schaffer collateral-CA1 synapses. Nat. Neurosci. 11, 170177.

85 Savic, N., Pedarzani, P. and Sciancalepore, M. (2001) Medium afterhyperpolarization and firing pattern modulation in interneurons of stratum radiatum in the CA3 hippocampal region. J. Neurophysiol. 85, 1986-1997.

86 Blank, T., Nijholt, I., Kye, M. J., Radulovic, J. and Spiess, J. (2003) Small-conductance, $\mathrm{Ca}^{2+}$-activated $\mathrm{K}^{+}$channel SK3 generates age-related memory and LTP deficits. Nat. Neurosci. 6, 911-912.

87 Schwindt, P. C., Spain, W. J., Foehring, R. C., Chubb, M. C. and Crill, W. E. (1988) Slow conductances in neurons from cat sensorimotor cortex in vitro and their role in slow excitability changes. J. Neurophysiol. 59, 450-467.

88 Lorenzon, N. M. and Foehring, R. C. (1992) Relationship between repetitive firing and afterhyperpolarizations in human neocortical neurons. J. Neurophysiol. 67, 350-363.

89 Schwindt, P. C., Spain, W. J. and Crill, W. E. (1992) Calciumdependent potassium currents in neurons from cat sensorimotor cortex. J. Neurophysiol. 67, 216-226.

90 Pineda, J. C., Waters, R. S. and Foehring, R. C. (1998) Specificity in the interaction of HVA $\mathrm{Ca}^{2+}$ channel types with $\mathrm{Ca}^{2+}$-dependent AHPs and firing behavior in neocortical pyramidal neurons. J. Neurophysiol. 79, 2522-2534.

91 Yamada, S., Takechi, H., Kanchiku, I., Kita, T. and Kato, N. (2004) Small-conductance $\mathrm{Ca}^{2+}$-dependent $\mathrm{K}^{+}$channels are the target of spike-induced $\mathrm{Ca}^{2+}$ release in a feedback regulation of pyramidal cell excitability. J. Neurophysiol. 91, $2322-2329$.

92 Gulledge, A. T., Park, S. B., Kawaguchi, Y. and Stuart, G. J. (2007) Heterogeneity of phasic cholinergic signaling in neocortical neurons. J. Neurophysiol. 97, 2215-2229.

93 Sourdet, V., Russier, M., Daoudal, G., Ankri, N. and Debanne, D. (2003) Long-term enhancement of neuronal excitability and temporal fidelity mediated by metabotropic glutamate receptor subtype 5. J. Neurosci. 23, 10238-10248.

94 Villalobos, C., Shakkottai, V. G., Chandy, K. G., Michelhaugh, S. K. and Andrade, R. (2004) SKCa channels mediate the medium but not the slow calcium-activated afterhyperpolarization in cortical neurons. J. Neurosci. 24, 3537-3542.

95 Oh, M. M., Power, J. M., Thompson, L. T. and Disterhoft, J. F. (2000) Apamin increases excitability of CA1 hippocampal pyramidal neurons. Neurosci. Res. Commun. 27, 135-142.

96 Kramar, E. A., Lin, B., Lin, C. Y., Arai, A. C., Gall, C. M. and Lynch, G. (2004) A novel mechanism for the facilitation of theta-induced long-term potentiation by brain-derived neurotrophic factor. J. Neurosci. 24, 5151-5161.

97 Shah, M. M., Javadzadeh-Tabatabaie, M., Benton, D. C., Ganellin, C. R. and Haylett, D. G. (2006) Enhancement of hippocampal pyramidal cell excitability by the novel selective slow-afterhyperpolarization channel blocker 3-(triphenylmethylaminomethyl)pyridine (UCL2077). Mol. Pharmacol. 70, $1494-1502$.

98 Cai, X., Wei, D. S., Gallagher, S. E., Bagal, A., Mei, Y. A., Kao, J. P., Thompson, S. M. and Tang, C. M. (2007) Hyperexcitability of distal dendrites in hippocampal pyramidal cells after chronic partial deafferentation. J. Neurosci. 27, 59-68.

99 Kaczorowski, C. C., Disterhoft, J. and Spruston, N. (2007) Stability and plasticity of intrinsic membrane properties in hippocampal CA1 pyramidal neurons: Effects of internal anions. J. Physiol. 578, 799-818. 
$100 \mathrm{Gu}$, N., Vervaeke, K., Hu, H. and Storm, J. F. (2005) Kv7/ $\mathrm{KCNQ} / \mathrm{M}$ and $\mathrm{HCN} / \mathrm{h}$, but not $\mathrm{K}_{\mathrm{Ca}} 2 / \mathrm{SK}$ channels, contribute to the somatic medium after-hyperpolarization and excitability control in CA1 hippocampal pyramidal cells. J. Physiol. 566, 689-715.

101 Shah, M. M. and Haylett, D. G. (2002) K ${ }^{+}$currents generated by NMDA receptor activation in rat hippocampal pyramidal neurons. J. Neurophysiol. 87, 2983-2989.

102 Cai, X., Liang, C. W., Muralidharan, S., Kao, J. P., Tang, C. M. and Thompson, S. M. (2004) Unique roles of SK and Kv4.2 potassium channels in dendritic integration. Neuron 44, 351364.

103 Faber, E. S., Delaney, A. J. and Sah, P. (2005) SK channels regulate excitatory synaptic transmission and plasticity in the lateral amygdala. Nat. Neurosci. 8, 635-641.

104 Ngo-Anh, T. J., Bloodgood, B. L., Lin, M., Sabatini, B. L., Maylie, J. and Adelman, J. P. (2005) SK channels and NMDA receptors form a $\mathrm{Ca}^{2+}$-mediated feedback loop in dendritic spines. Nat. Neurosci. 8, 642-649.

105 Bloodgood, B. L. and Sabatini, B. L. (2007) Nonlinear regulation of unitary synaptic signals by $\mathrm{Ca}_{\mathrm{V}} 2.3$ voltagesensitive calcium channels located in dendritic spines. Neuron $53,249-260$

106 Lynch, M. A. (2004) Long-term potentiation and memory. Physiol. Rev. 84, 87-136.

107 Cavazzini, M., Bliss, T. and Emptage, N. (2005) $\mathrm{Ca}^{2+}$ and synaptic plasticity. Cell Calcium 38, 355-367.

108 Behnisch, T. and Reymann, K. G. (1998) Inhibition of apaminsensitive calcium dependent potassium channels facilitate the induction of long-term potentiation in the CA1 region of rat hippocampus in vitro. Neurosci. Lett. 253, 91-94.

109 Stackman, R. W., Hammond, R. S., Linardatos, E., Gerlach, A., Maylie, J., Adelman, J. P. and Tzounopoulos, T. (2002) Small conductance $\mathrm{Ca}^{2+}$-activated $\mathrm{K}^{+}$channels modulate synaptic plasticity and memory encoding. J. Neurosci. 22, 10163-10171.

110 Hammond, R. S., Bond, C. T., Strassmaier, T., Ngo-Anh, T. J., Adelman, J. P., Maylie, J. and Stackman, R. W. (2006) Smallconductance $\mathrm{Ca}^{2+}$-activated $\mathrm{K}^{+}$channel type 2 (SK2) modulates hippocampal learning, memory, and synaptic plasticity. J. Neurosci. 26, 1844-1853.

111 Stackman, R. W., Jr., Bond, C. T. and Adelman, J. P. (2008) Contextual memory deficits observed in mice overexpressin small conductance $\mathrm{Ca}^{2+}$-activated $\mathrm{K}^{+}$type $2\left(\mathrm{~K}_{\mathrm{Ca}} 2.2\right.$, SK2) channels are caused by an encoding deficit. Learn Mem 15, 208-213.

112 Faber, E. S. and Sah, P. (2002) Physiological role of calciumactivated potassium currents in the rat lateral amygdala. J. Neurosci. 22, 1618-1628.

113 Sah, P., Faber, E. S., Lopez De Armentia, M. and Power, J. (2003) The amygdaloid complex: Anatomy and physiology. Physiol. Rev. 83, 803-834.

114 Bildl, W., Strassmaier, T., Thurm, H., Andersen, J., Eble, S., Oliver, D., Knipper, M., Mann, M., Schulte, U., Adelman, J. P. and Fakler, B. (2004) Protein kinase CK2 is coassembled with small conductance $\mathrm{Ca}^{2+}$-activated $\mathrm{K}^{+}$channels and regulates channel gating. Neuron $43,847-858$.

115 Allen, D., Fakler, B., Maylie, J. and Adelman, J. P. (2007) Organization and regulation of small conductance $\mathrm{Ca}^{2+}$. activated $\mathrm{K}^{+}$channel multiprotein complexes. J. Neurosci. 27, 2369-2376.

116 Gallo, G., Ernst, A. F., McLoon, S. C. and Letourneau, P. C. (2002) Transient PKA activity is required for initiation but not maintenance of BDNF-mediated protection from nitric oxide-induced growth-cone collapse. J. Neurosci. 22, 50165023.

117 Ren, Y., Barnwell, L. F., Alexander, J. C., Lubin, F. D., Adelman, J. P., Pfaffinger, P. J., Schrader, L. A. and Anderson, A. E. (2006) Regulation of surface localization of the small conductance $\mathrm{Ca}^{2+}$-activated potassium channel, $\mathrm{Sk} 2$, through direct phosphorylation by cAMP-dependent protein kinase. J. Biol. Chem. 281, 11769-11779.
118 Martina, M., Turcotte, M. E., Halman, S. and Bergeron, R. (2007) The sigma-1 receptor modulates NMDA receptor synaptic transmission and plasticity via SK channels in rat hippocampus. J. Physiol. 578, 143-157.

119 Sarpal, D., Koenig, J. I., Adelman, J. P., Brady, D., Prendeville, L. C. and Shepard, P. D. (2004) Regional distribution of SK3 mRNA-containing neurons in the adult and adolescent rat ventral midbrain and their relationship to dopamine-containing cells. Synapse 53, 104-113.

120 Wolfart, J., Neuhoff, H., Franz, O. and Roeper, J. (2001) Differential expression of the small-conductance, calciumactivated potassium channel SK3 is critical for pacemaker control in dopaminergic midbrain neurons. J. Neurosci. 21, $3443-3456$.

121 Goldman-Rakic, P. S. (1999) The physiological approach: Functional architecture of working memory and disordered cognition in schizophrenia. Biol. Psychiatry 46, 650-661.

122 Kitai, S. T., Shepard, P. D., Callaway, J. C. and Scroggs, R. (1999) Afferent modulation of dopamine neuron firing patterns. Curr. Opin. Neurobiol. 9, 690-697.

123 Spanagel, R. and Weiss, F. (1999) The dopamine hypothesis of reward: Past and current status. Trends Neurosci. 22, 521527.

124 Schultz, W. (2000) Multiple reward signals in the brain. Nat. Rev. Neurosci. 1, 199-207.

125 Floresco, S. B., West, A. R., Ash, B., Moore, H. and Grace, A. A. (2003) Afferent modulation of dopamine neuron firing differentially regulates tonic and phasic dopamine transmission. Nat. Neurosci. 6, 968-973.

126 Wilson, C. J., Young, S. J. and Groves, P. M. (1977) Statistical properties of neuronal spike trains in the substantia nigra: Cell types and their interactions. Brain Res. 136, 243-260.

127 Sanghera, M. K., Trulson, M. E. and German, D. C. (1984) Electrophysiological properties of mouse dopamine neurons: In vivo and in vitro studies. Neuroscience 12, 793-801.

128 Grace, A. A. and Bunney, B. S. (1984) The control of firing pattern in nigral dopamine neurons: Burst firing. J. Neurosci. 4, 2877-2890.

129 Grace, A. A. and Bunney, B. S. (1984) The control of firing pattern in nigral dopamine neurons: Single spike firing. J. Neurosci. 4, 2866-2876.

130 Freeman, A. S., Meltzer, L. T. and Bunney, B. S. (1985) Firing properties of substantia nigra dopaminergic neurons in freely moving rats. Life Sci. 36, 1983-1994.

131 Waroux, O., Massotte, L., Alleva, L., Graulich, A., Thomas, E., Liegeois, J. F., Scuvee-Moreau, J. and Seutin, V. (2005) SK channels control the firing pattern of midbrain dopaminergic neurons in vivo. Eur. J. Neurosci. 22, 3111-3121.

132 Kita, T., Kita, H. and Kitai, S. T. (1986) Electrical membrane properties of rat substantia nigra compacta neurons in an in vitro slice preparation. Brain Res. 372, 21-30.

133 Grace, A. A. and Onn, S. P. (1989) Morphology and electrophysiological properties of immunocytochemically identified rat dopamine neurons recorded in vitro. J. Neurosci. 9, 34633481.

134 Lacey, M. G., Mercuri, N. B. and North, R. A. (1989) Two cell types in rat substantia nigra zona compacta distinguished by membrane properties and the actions of dopamine and opioids. J. Neurosci. 9, 1233-1241.

135 Kang, Y. and Kitai, S. T. (1993) Calcium spike underlying rhythmic firing in dopaminergic neurons of the rat substantia nigra. Neurosci. Res. 18, 195-207.

136 Overton, P. G. and Clark, D. (1997) Burst firing in midbrain dopaminergic neurons. Brain Res. Brain Res. Rev. 25, 312 334.

137 Wolfart, J. and Roeper, J. (2002) Selective coupling of T-type calcium channels to SK potassium channels prevents intrinsic bursting in dopaminergic midbrain neurons. J. Neurosci. 22, 3404-3413.

138 Shepard, P. D. and Bunney, B. S. (1988) Effects of apamin on the discharge properties of putative dopamine-containing neurons in vitro. Brain Res. 463, 380-384. 
139 Shepard, P. D. and Bunney, B. S. (1991) Repetitive firing properties of putative dopamine-containing neurons in vitro: Regulation by an apamin-sensitive $\mathrm{Ca}^{2+}$-activated $\mathrm{K}^{+}$conductance. Exp. Brain Res. 86, 141-150.

$140 \mathrm{Gu}$, X., Blatz, A. L. and German, D. C. (1992) Subtypes of substantia nigra dopaminergic neurons revealed by apamin: Autoradiographic and electrophysiological studies. Brain Res. Bull. 28, 435-440.

141 Ping, H. X. and Shepard, P. D. (1996) Apamin-sensitive $\mathrm{Ca}^{2+}$. activated $\mathrm{K}^{+}$channels regulate pacemaker activity in nigral dopamine neurons. Neuroreport 7, 809-814.

142 Seutin, V., Johnson, S. W. and North, R. A. (1993) Apamin increases NMDA-induced burst-firing of rat mesencephalic dopamine neurons. Brain Res. 630, 341-344.

143 Johnson, S. W. and Seutin, V. (1997) Bicuculline methiodide potentiates NMDA-dependent burst firing in rat dopamine neurons by blocking apamin-sensitive $\mathrm{Ca}^{2+}$-activated $\mathrm{K}^{+}$ currents. Neurosci. Lett. 231, 13-16.

$144 \mathrm{Ji}, \mathrm{H}$. and Shepard, P. D. (2006) SK Ca ${ }^{2+}$-activated $\mathrm{K}^{+}$channel ligands alter the firing pattern of dopamine-containing neurons in vivo. Neuroscience 140, 623-633.

145 Riegel, A. C. and Lupica, C. R. (2004) Independent presynaptic and postsynaptic mechanisms regulate endocannabinoid signaling at multiple synapses in the ventral tegmental area. J. Neurosci. 24, 11070-11078

146 Yanovsky, Y., Zhang, W. and Misgeld, U. (2005) Two pathways for the activation of small-conductance potassium channels in neurons of substantia nigra pars reticulata. Neuroscience 136, 1027-1036.

147 Yanovsky, Y., Velte, S. and Misgeld, U. (2006) $\mathrm{Ca}^{2+}$ releasedependent hyperpolarizations modulate the firing pattern of juvenile GABA neurons in mouse substantia nigra pars reticulata in vitro. J. Physiol. 577, 879-890.

148 Seutin, V., Massotte, L., Scuvee-Moreau, J. and Dresse, A. (1998) Spontaneous apamin-sensitive hyperpolarizations in dopaminergic neurons of neonatal rats. J. Neurophysiol. 80, $3361-3364$.

149 Seutin, V., Mkahli, F., Massotte, L. and Dresse, A. (2000) Calcium release from internal stores is required for the generation of spontaneous hyperpolarizations in dopaminergic neurons of neonatal rats. J. Neurophysiol. 83, 192-197.

150 Hallworth, N. E., Wilson, C. J. and Bevan, M. D. (2003) Apamin-sensitive small conductance calcium-activated potassium channels, through their selective coupling to voltagegated calcium channels, are critical determinants of the precision, pace, and pattern of action potential generation in rat subthalamic nucleus neurons in vitro. J. Neurosci. 23 , $7525-7542$

151 Wichmann, T., Bergman, H. and DeLong, M. R. (1994) The primate subthalamic nucleus. I. Functional properties in intact animals. J. Neurophysiol. 72, 494-506.

152 Levy, R., Hutchison, W. D., Lozano, A. M. and Dostrovsky, J. O. (2000) High-frequency synchronization of neuronal activity in the subthalamic nucleus of parkinsonian patients with limb tremor. J. Neurosci. 20, 7766-7775.

153 Reynolds, J. N., Hyland, B. I. and Wickens, J. R. (2004) Modulation of an afterhyperpolarization by the substantia nigra induces pauses in the tonic firing of striatal cholinergic interneurons. J. Neurosci. 24, 9870-9877.

154 Wilson, C. J. and Goldberg, J. A. (2006) Origin of the slow afterhyperpolarization and slow rhythmic bursting in striatal cholinergic interneurons. J. Neurophysiol. 95, 196-204.

155 Bennett, B. D., Callaway, J. C. and Wilson, C. J. (2000) Intrinsic membrane properties underlying spontaneous tonic firing in neostriatal cholinergic interneurons. J. Neurosci. 20, $8493-8503$.

156 Goldberg, J. A. and Wilson, C. J. (2005) Control of spontaneous firing patterns by the selective coupling of calcium currents to calcium-activated potassium currents in striatal cholinergic interneurons. J. Neurosci. 25, 10230-10238.

157 Cingolani, L. A., Gymnopoulos, M., Boccaccio, A., Stocker, M. and Pedarzani, P. (2002) Developmental regulation of small-conductance $\mathrm{Ca}^{2+}$-activated $\mathrm{K}^{+}$channel expression and function in rat Purkinje neurons. J. Neurosci. 22, 4456-4467.

158 Edgerton, J. R. and Reinhart, P. H. (2003) Distinct contributions of small and large conductance $\mathrm{Ca}^{2+}$-activated $\mathrm{K}^{+}$ channels to rat Purkinje neuron function. J. Physiol. 548, 53-69.

159 Womack, M. D. and Khodakhah, K. (2003) Somatic and dendritic small-conductance calcium-activated potassium channels regulate the output of cerebellar purkinje neurons. J. Neurosci. 23, 2600-2607.

160 Womack, M. D., Chevez, C. and Khodakhah, K. (2004) Calcium-activated potassium channels are selectively coupled to P/Q-type calcium channels in cerebellar Purkinje neurons. J. Neurosci. 24, 8818-8822.

161 Womack, M. D. and Khodakhah, K. (2004) Dendritic control of spontaneous bursting in cerebellar Purkinje cells. J. Neurosci. 24, 3511-3521.

162 Forti, L., Cesana, E., Mapelli, J. and D’Angelo, E. (2006) Ionic mechanisms of autorhythmic firing in rat cerebellar Golgi cells. J. Physiol. 574, 711-729.

163 Aizenman, C. D. and Linden, D. J. (1999) Regulation of the rebound depolarization and spontaneous firing patterns of deep nuclear neurons in slices of rat cerebellum. J. Neurophysiol. 82, 1697-1709.

164 Czubayko, U., Sultan, F., Thier, P. and Schwarz, C. (2001) Two types of neurons in the rat cerebellar nuclei as distinguished by membrane potentials and intracellular fillings. J. Neurophysiol. 85, 2017-2029.

165 Alvina, K. and Khodakhah, K. (2008) Selective regulation of spontaneous activity of neurons of the deep cerebellar nuclei by $\mathrm{N}$-type calcium channels in juvenile rats. J. Physiol. 586, $2523-2538$.

166 Jahnsen, H. (1986) Electrophysiological characteristics of neurones in the guinea-pig deep cerebellar nuclei in vitro. J. Physiol. 372, 129-147.

167 Armstrong, W. E., Rubrum, A., Teruyama, R., Bond, C. T. and Adelman, J. P. (2005) Immunocytochemical localization of small-conductance, calcium-dependent potassium channels in astrocytes of the rat supraoptic nucleus. J. Comp. Neurol. 491, 175-185.

168 Fujita, A., Takeuchi, T., Hanai, J. and Hata, F. (2003) Expression of the small conductance $\mathrm{Ca}^{2+}$-activated $\mathrm{K}^{+}$ channel, SK3, in the olfactory ensheathing glial cells of rat brain. Cell Tissue Res. 313, 187-193.

169 Verkhratsky, A., Orkand, R. K. and Kettenmann, H. (1998) Glial calcium: Homeostasis and signaling function. Physiol. Rev. 78, 99-141.

170 Jalonen, T. O., Margraf, R. R., Wielt, D. B., Charniga, C. J., Linne, M. L. and Kimelberg, H. K. (1997) Serotonin induces inward potassium and calcium currents in rat cortical astrocytes. Brain Res. 758, 69-82.

171 Bychkov, R., Glowinski, J. and Giaume, C. (2001) Sequential and opposite regulation of two outward $\mathrm{K}^{+}$currents by ET-1 in cultured striatal astrocytes. Am. J. Physiol. Cell Physiol. 281, C1373-1384.

172 Rock, R. B., Gekker, G., Hu, S., Sheng, W. S., Cheeran, M., Lokensgard, J. R. and Peterson, P. K. (2004) Role of microglia in central nervous system infections. Clin. Microbiol. Rev. 17, 942-964.

173 Khanna, R., Roy, L., Zhu, X. and Schlichter, L. C. (2001) K ${ }^{+}$ channels and the microglial respiratory burst. Am. J. Physiol. Cell Physiol. 280, C796-806.

174 Schilling, T., Repp, H., Richter, H., Koschinski, A., Heinemann, U., Dreyer, F. and Eder, C. (2002) Lysophospholipids induce membrane hyperpolarization in microglia by activation of IKCa1 $\mathrm{Ca}^{2+}$-dependent $\mathrm{K}^{+}$channels. Neuroscience $109,827-835$.

175 Schilling, T., Stock, C., Schwab, A. and Eder, C. (2004) Functional importance of $\mathrm{Ca}^{2+}$-activated $\mathrm{K}^{+}$channels for lysophosphatidic acid-induced microglial migration. Eur. J. Neurosci. 19, 1469-1474. 
176 Kaushal, V., Koeberle, P. D., Wang, Y. and Schlichter, L. C. (2007) The $\mathrm{Ca}^{2+}$-activated $\mathrm{K}^{+}$channel $\mathrm{KCNN} 4 / \mathrm{KCa} 3.1$ contributes to microglia activation and nitric oxide-dependent neurodegeneration. J. Neurosci. 27, 234-244.

177 Feletou, M. and Vanhoutte, P. M. (2006) Endotheliumderived hyperpolarizing factor: Where are we now? Arterioscler. Thromb. Vasc. Biol. 26, 1215-1225.

178 Busse, R., Edwards, G., Feletou, M., Fleming, I., Vanhoutte, P. M. and Weston, A. H. (2002) EDHF: Bringing the concepts together. Trends Pharmacol. Sci. 23, 374-380.

179 Edwards, G. and Weston, A. H. (2004) Potassium and potassium clouds in endothelium-dependent hyperpolarizations. Pharmacol. Res. 49, 535-541.

180 Taylor, S. G. and Weston, A. H. (1988) Endothelium-derived hyperpolarizing factor: A new endogenous inhibitor from the vascular endothelium. Trends Pharmacol. Sci. 9, 272-274.

181 Taylor, M. S., Bonev, A. D., Gross, T. P., Eckman, D. M., Brayden, J. E., Bond, C. T., Adelman, J. P. and Nelson, M. T. (2003) Altered expression of small-conductance $\mathrm{Ca}^{2+}$-activated $\mathrm{K}^{+}$(SK3) channels modulates arterial tone and blood pressure. Circ. Res. 93, 124-131.

182 Si, H., Heyken, W. T., Wolfle, S. E., Tysiac, M., Schubert, R., Grgic, I., Vilianovich, L., Giebing, G., Maier, T., Gross, V., Bader, M., de Wit, C., Hoyer, J. and Kohler, R. (2006) Impaired endothelium-derived hyperpolarizing factor-mediated dilations and increased blood pressure in mice deficient of the intermediate-conductance $\mathrm{Ca}^{2+}$-activated $\mathrm{K}^{+}$channel. Circ. Res. 99, 537-544.

183 Burnham, M. P., Bychkov, R., Feletou, M., Richards, G. R. Vanhoutte, P. M., Weston, A. H. and Edwards, G. (2002) Characterization of an apamin-sensitive small-conductance $\mathrm{Ca}^{2+}$-activated $\mathrm{K}^{+}$channel in porcine coronary artery endothelium: Relevance to EDHF. Br. J. Pharmacol. 135, 1133 1143.

184 Bychkov, R., Burnham, M. P., Richards, G. R., Edwards, G., Weston, A. H., Feletou, M. and Vanhoutte, P. M. (2002) Characterization of a charybdotoxin-sensitive intermediate conductance $\mathrm{Ca}^{2+}$-activated $\mathrm{K}^{+}$channel in porcine coronary endothelium: Relevance to EDHF. Br. J. Pharmacol. 137, 1346-1354.

185 Marrelli, S. P., Eckmann, M. S. and Hunte, M. S. (2003) Role of endothelial intermediate conductance $\mathrm{K}_{\mathrm{Ca}}$ channels in cerebral EDHF-mediated dilations. Am. J. Physiol. Heart Circ. Physiol. 285, H1590-1599.

186 McNeish, A. J., Dora, K. A. and Garland, C. J. (2005) Possible role for $\mathrm{K}^{+}$in endothelium-derived hyperpolarizing factorlinked dilatation in rat middle cerebral artery. Stroke 36, $1526-1532$.

187 McNeish, A. J., Sandow, S. L., Neylon, C. B., Chen, M. X., Dora, K. A. and Garland, C. J. (2006) Evidence for involvement of both $\mathrm{IK}_{\mathrm{Ca}}$ and $\mathrm{SK}_{\mathrm{Ca}}$ channels in hyperpolarizing responses of the rat middle cerebral artery. Stroke 37, $1277-$ 1282.

188 Faraci, F. M., Lynch, C. and Lamping, K. G. (2004) Responses of cerebral arterioles to ADP: eNOS-dependent and eNOSindependent mechanisms. Am. J. Physiol. Heart Circ. Physiol. 287, H2871-2876.

189 Sander, T., Scholz, L., Janz, D., Epplen, J. T. and Riess, O. (1999) Length variation of a polyglutamine array in the gene encoding a small-conductance, calcium-activated potassium channel (hKCa3) and susceptibility to idiopathic generalized epilepsy. Epilepsy Res. 33, 227-233.

190 Fernandez de Sevilla, D., Garduno, J., Galvan, E. and Buno, W. (2006) Calcium-activated afterhyperpolarizations regulate synchronization and timing of epileptiform bursts in hippocampal CA3 pyramidal neurons. J. Neurophysiol. 96, 30283041.

191 Empson, R. M. and Jefferys, J. G. (2001) $\mathrm{Ca}^{2+}$ entry through Ltype $\mathrm{Ca}^{2+}$ channels helps terminate epileptiform activity by activation of a $\mathrm{Ca}^{2+}$ dependent afterhyperpolarisation in hippocampal CA3. Neuroscience 102, 297-306.
192 Garduno, J., Galvan, E., Fernandez de Sevilla, D. and Buno, W. (2005) 1-Ethyl-2-benzimidazolinone (EBIO) suppresses epileptiform activity in in vitro hippocampus. Neuropharmacology 49, 376-388.

193 Lappin, S. C., Dale, T. J., Brown, J. T., Trezise, D. J. and Davies, C. H. (2005) Activation of SK channels inhibits epileptiform bursting in hippocampal CA3 neurons. Brain Res. 1065, 37-46.

194 Anderson, N. J., Slough, S. and Watson, W. P. (2006) In vivo characterisation of the small-conductance $\mathrm{K}_{\mathrm{Ca}}(\mathrm{SK})$ channel activator 1-ethyl-2-benzimidazolinone (1-EBIO) as a potential anticonvulsant. Eur. J. Pharmacol. 546, 48-53.

195 Pietrobon, D. (2005) Function and dysfunction of synaptic calcium channels: Insights from mouse models. Curr. Opin. Neurobiol. 15, 257-265.

196 Donato, R., Page, K. M., Koch, D., Nieto-Rostro, M., Foucault, I., Davies, A., Wilkinson, T., Rees, M., Edwards, F. A. and Dolphin, A. C. (2006) The ducky ${ }^{2 J}$ mutation in Cacna2d2 results in reduced spontaneous Purkinje cell activity and altered gene expression. J. Neurosci. 26, 1257612586.

197 Walter, J. T., Alvina, K., Womack, M. D., Chevez, C. and Khodakhah, K. (2006) Decreases in the precision of Purkinje cell pacemaking cause cerebellar dysfunction and ataxia. Nat. Neurosci. 9, 389-397.

198 Otis, T. S. and Jen, J. C. (2006) Blessed are the pacemakers. Nat. Neurosci. 9, 297-298.

199 Figueroa, K. P., Chan, P., Schols, L., Tanner, C., Riess, O., Perlman, S. L., Geschwind, D. H. and Pulst, S. M. (2001) Association of moderate polyglutamine tract expansions in the slow calcium-activated potassium channel type 3 with ataxia. Arch. Neurol. 58, 1649-1653.

200 Gonon, F. G. and Buda, M. J. (1985) Regulation of dopamine release by impulse flow and by autoreceptors as studied by in vivo voltammetry in the rat striatum. Neuroscience $14,765-$ 774.

201 Bean, A. J. and Roth, R. H. (1991) Extracellular dopamine and neurotensin in rat prefrontal cortex in vivo: Effects of median forebrain bundle stimulation frequency, stimulation pattern, and dopamine autoreceptors. J. Neurosci. 11, 26942702.

202 Grace, A. A. (1991) Phasic versus tonic dopamine release and the modulation of dopamine system responsivity: A hypothesis for the etiology of schizophrenia. Neuroscience 41,1-24.

203 Dunnett, S. B. and Bjorklund, A. (1999) Prospects for new restorative and neuroprotective treatments in Parkinson's disease. Nature 399, A32-39.

204 Grace, A. A. (2000) Gating of information flow within the limbic system and the pathophysiology of schizophrenia. Brain Res. Brain Res. Rev. 31, 330-341.

205 Svensson, T. H. (2000) Dysfunctional brain dopamine systems induced by psychotomimetic NMDA-receptor antagonists and the effects of antipsychotic drugs. Brain Res. Brain Res. Rev. 31, 320-329.

206 Salthun-Lassalle, B., Hirsch, E. C., Wolfart, J., Ruberg, M. and Michel, P. P. (2004) Rescue of mesencephalic dopaminergic neurons in culture by low-level stimulation of voltagegated sodium channels. J. Neurosci. 24, 5922-5930.

207 Gargus, J. J., Fantino, E. and Gutman, G. A. (1998) A piece in the puzzle: An ion channel candidate gene for schizophrenia. Mol. Med. Today 4, 518-524.

208 Wittekindt, O., Jauch, A., Burgert, E., Scharer, L., HoltgreveGrez, H., Yvert, G., Imbert, G., Zimmer, J., Hoehe, M. R., Macher, J. P., Chiaroni, P., van Calker, D., Crocq, M. A. and Morris-Rosendahl, D. J. (1998) The human small conductance calcium-regulated potassium channel gene (hSKCa3) contains two CAG repeats in exon 1, is on chromosome 1q21.3, and shows a possible association with schizophrenia. Neurogenetics 1, 259-265.

209 Brzustowicz, L. M., Hodgkinson, K. A., Chow, E. W., Honer, W. G. and Bassett, A. S. (2000) Location of a major 
susceptibility locus for familial schizophrenia on chromosome 1q21-q22. Science 288, 678-682.

210 Chandy, K. G., Fantino, E., Wittekindt, O., Kalman, K., Tong, L. L., Ho, T. H., Gutman, G. A., Crocq, M. A., Ganguli, R., Nimgaonkar, V., Morris-Rosendahl, D. J. and Gargus, J. J. (1998) Isolation of a novel potassium channel gene hSKCa3 containing a polymorphic CAG repeat: A candidate for schizophrenia and bipolar disorder? Mol. Psychiatry 3, $32-$ 37.

211 Bowen, T., Guy, C. A., Craddock, N., Cardno, A. G., Williams, N. M., Spurlock, G., Murphy, K. C., Jones, L. A., Gray, M., Sanders, R. D., McCarthy, G., Chandy, K. G., Fantino, E., Kalman, K., Gutman, G. A., Gargus, J. J., Williams, J., McGuffin, P., Owen, M. J. and O’Donovan, M. C. (1998) Further support for an association between a polymorphic CAG repeat in the hKCa3 gene and schizophrenia. Mol. Psychiatry 3, 266-269.

212 Dror, V., Shamir, E., Ghanshani, S., Kimhi, R., Swartz, M., Barak, Y., Weizman, R., Avivi, L., Litmanovitch, T., Fantino, E., Kalman, K., Jones, E. G., Chandy, K. G., Gargus, J. J., Gutman, G. A. and Navon, R. (1999) hKCa3/KCNN3 potassium channel gene: Association of longer CAG repeats with schizophrenia in Israeli Ashkenazi Jews, expression in human tissues and localization to chromosome 1q21. Mol. Psychiatry 4, 254-260.

213 Ivkovic, M., Rankovic, V., Tarasjev, A., Orolicki, S., Damjanovic, A., Paunovic, V. R. and Romac, S. (2006) Schizophrenia and polymorphic CAG repeats array of calciumactivated potassium channel $(K C N N 3)$ gene in Serbian population. Int. J. Neurosci. 116, 157-164.

214 Ritsner, M., Modai, I., Ziv, H., Amir, S., Halperin, T., Weizman, A. and Navon, R. (2002) An association of CAG repeats at the KCNN3 locus with symptom dimensions of schizophrenia. Biol. Psychiatry. 51, 788-794.

215 Ritsner, M., Amir, S., Koronyo-Hamaoui, M., Gak, E., Ziv, H., Halperin, T., Kitain, L. and Navon, R. (2003) Association study of CAG repeats in the KCNN3 gene in Israeli patients with major psychosis. Psychiatr. Genet. 13, 143-150.

216 Bonnet-Brilhault, F., Laurent, C., Campion, D., Thibaut, F., Lafargue, C., Charbonnier, F., Deleuze, J. F., Menard, J. F., Jay, M., Petit, M., Frebourg, T. and Mallet, J. (1999) No evidence for involvement of KCNN3 (hSKCa3) potassium channel gene in familial and isolated cases of schizophrenia. Eur. J. Hum. Genet. 7, 247-250.

217 Joober, R., Benkelfat, C., Brisebois, K., Toulouse, A., Lafreniere, R. G., Turecki, G., Lal, S., Bloom, D., Labelle, A., Lalonde, P., Fortin, D., Alda, M., Palmour, R. and Rouleau, G. A. (1999) Lack of association between the hSKCa3 channel gene CAG polymorphism and schizophrenia. Am. J. Med. Genet. 88, 154-157.

218 Tsai, M. T., Shaw, C. K., Hsiao, K. J. and Chen, C. H. (1999) Genetic association study of a polymorphic CAG repeats array of calcium-activated potassium channel $(K C N N 3)$ gene and schizophrenia among the Chinese population from Taiwan. Mol. Psychiatry 4, 271-273.

219 Saleem, Q., Sreevidya, V. S., Sudhir, J., Savithri, J. V., Gowda, Y., C, B. R., Benegal, V., Majumder, P. P., Anand, A., Brahmachari, S. K. and Jain, S. (2000) Association analysis of CAG repeats at the KCNN3 locus in Indian patients with bipolar disorder and schizophrenia. Am. J. Med. Genet. 96, $744-748$.

220 Imamura, A., Tsujita, T., Kayashima, T., Oda, R., Kikuchi, T., Hayashida, M., Hamada, A., Fujimaru, K., Matsumoto, S., Hashida, A., Nakane, Y. and Okazaki, Y. (2001) Lack of association between the hKCa3 gene and Japanese schizophrenia patients. Psychiatr. Genet. 11, 227-229.

221 Ujike, H., Yamamoto, A., Tanaka, Y., Takehisa, Y., Takaki, M., Taked, T., Kodama, M. and Kuroda, S. (2001) Association study of CAG repeats in the KCNN3 gene in Japanese patients with schizophrenia, schizoaffective disorder and bipolar disorder. Psychiatry Res. 101, 203-207.
222 Laurent, C., Niehaus, D., Bauche, S., Levinson, D. F., Soubigou, S., Pimstone, S., Hayden, M., Mbanga, I., Emsley, R., Deleuze, J. F. and Mallet, J. (2003) CAG repeat polymorphisms in KCNN3 (HSKCa3) and PPP2R2B show no association or linkage to schizophrenia. Am. J. Med. Genet. B Neuropsychiatr. Genet. 116, 45-50.

223 Li, T., Hu, X., Chandy, K. G., Fantino, E., Kalman, K., Gutman, G., Gargus, J. J., Freeman, B., Murray, R. M., Dawson, E., Liu, X., Bruinvels, A. T., Sham, P. C. and Collier, D. A. (1998) Transmission disequilibrium analysis of a triplet repeat within the hKCa3 gene using family trios with schizophrenia. Biochem. Biophys. Res. Commun. 251, 662665.

224 Stober, G., Jatzke, S., Meyer, J., Okladnova, O., Knapp, M., Beckmann, H. and Lesch, K. P. (1998) Short CAG repeats within the hSKCa3 gene associated with schizophrenia: Results of a family-based study. Neuroreport 9, 3595-3599.

225 Antonarakis, S. E., Blouin, J. L., Lasseter, V. K., Gehrig, C., Radhakrishna, U., Nestadt, G., Housman, D. E., Kazazian, H. H., Kalman, K., Gutman, G., Fantino, E., Chandy, K. G., Gargus, J. J. and Pulver, A. E. (1999) Lack of linkage or association between schizophrenia and the polymorphic trinucleotide repeat within the $K C N N 3$ gene on chromosome 1q21. Am. J. Med. Genet. 88, 348-351.

226 Austin, C. P., Holder, D. J., Ma, L., Mixson, L. A. and Caskey, C. T. (1999) Mapping of hKCa3 to chromosome 1q21 and investigation of linkage of CAG repeat polymorphism to schizophrenia. Mol. Psychiatry 4, 261-266.

227 Hawi, Z., Mynett-Johnson, L., Murphy, V., Straub, R. E., Kendler, K. S., Walsh, D., McKeon, P. and Gill, M. (1999) No evidence to support the association of the potassium channel gene hSKCa3 CAG repeat with schizophrenia or bipolar disorder in the Irish population. Mol. Psychiatry 4, 488-491.

228 Meissner, B., Purmann, S., Schurmann, M., Zuhlke, C., Lencer, R., Arolt, V., Muller-Myhsok, B., Morris-Rosendahl, D. J. and Schwinger, E. (1999) hSKCa3: A candidate gene for schizophrenia? Psychiatr. Genet. 9, 91-96.

229 Wittekindt, O., Schwab, S. G., Burgert, E., Knapp, M., Albus, M., Lerer, B., Hallmayer, J., Rietschel, M., Segman, R., Borrmann, M., Lichtermann, D., Crocq, M. A., Maier, W., Morris-Rosendahl, D. J. and Wildenauer, D. B. (1999) Association between hSKCa3 and schizophrenia not confirmed by transmission disequilibrium test in 193 offspring/ parents trios. Mol. Psychiatry 4, 267-270.

230 Chowdari, K. V., Wood, J., Ganguli, R., Gottesman, II and Nimgaonkar, V. L. (2000) Lack of association between schizophrenia and a CAG repeat polymorphism of the hSKCa3 gene in a north eastern US sample. Mol. Psychiatry $5,237-238$

231 Bowen, T., Williams, N., Norton, N., Spurlock, G., Wittekindt, O. H., Morris-Rosendahl, D. J., Williams, H., Brzustowicz, L., Hoogendoorn, B., Zammit, S., Jones, G., Sanders, R. D., Jones, L. A., McCarthy, G., Jones, S., Bassett, A., Cardno, A. G., Owen, M. J. and O’Donovan, M. C. (2001) Mutation screening of the $K C N N 3$ gene reveals a rare frameshift mutation. Mol. Psychiatry 6, 259-260.

232 Miller, M. J., Rauer, H., Tomita, H., Rauer, H., Gargus, J. J., Gutman, G. A., Cahalan, M. D. and Chandy, K. G. (2001) Nuclear localization and dominant-negative suppression by a mutant SKCa3 N-terminal channel fragment identified in a patient with schizophrenia. J. Biol. Chem. 276, 27753-27756.

233 Guy, C. A., Bowen, T., Williams, N., Jones, I. R., McCandless, F., McGuffin, P., Owen, M. J., Craddock, N. and O'Donovan, M. C. (1999) No association between a polymorphic CAG repeat in the human potassium channel gene hSKCa3 and bipolar disorder. Am. J. Med. Genet. 88, 57-60.

234 McInnis, M. G., Breschel, T. S., Margolis, R. L., Chellis, J., MacKinnon, D. F., McMahon, F. J., Simpson, S. G., Lan, T. H., Chen, H., Ross, C. A. and DePaulo, J. R. (1999) Family-based association analysis of the $\mathrm{hSKCa} 3$ potassium channel gene in bipolar disorder. Mol. Psychiatry 4, 217-219. 
235 Rohrmeier, T., Putzhammer, A., Schoeler, A., Sartor, H. Dallinger, P., Nothen, M. M., Propping, P., Knapp, M., Albus, M., Borrmann, M., Knothe, K., Kreiner, R., Franzek, E. Lichtermann, D., Rietschel, M., Maier, W., Klein, H. E. and Eichhammer, P. (1999) hSKCa3: No association of the polymorphic CAG repeat with bipolar affective disorder and schizophrenia. Psychiatr. Genet. 9, 169-175.

236 Bowen, T., Ashworth, L., Kirov, G., Guy, C. A., Jones, I. R., McCandless, F., Craddock, N., O'Donovan, M. C. and Owen, M. J. (2000) No evidence of association from transmission disequilibrium analysis of the $\mathrm{hKCa} 3$ gene in bipolar disorder. Bipolar Disord. 2, 328-331.

237 Jin, D. K., Hwang, H. Z., Oh, M. R., Kim, J. S., Lee, M., Kim, S., Lim, S. W., Seo, M. Y., Kim, J. H. and Kim, D. K. (2001) CAG repeats of $C T G 18.1$ and $K C N N 3$ in Korean patients with bipolar affective disorder. J. Affect. Disord. 66, 19-24.

238 Meira-Lima, I. V., Zhao, J., Sham, P., Pereira, A. C., Krieger, J. E. and Vallada, H. (2001) Association and linkage studies between bipolar affective disorder and the polymorphic CAG/CTG repeat loci ERDA1, SEF2-1B,MAB21L and KCNN3. Mol. Psychiatry 6, 565-569.

239 Glatt, S. J., Faraone, S. V. and Tsuang, M. T. (2003) CAGrepeat length in exon 1 of $K C N N 3$ does not influence risk for schizophrenia or bipolar disorder: A meta-analysis of association studies. Am. J. Med. Genet. B Neuropsychiatr. Genet. 121, 14-20.

240 Koronyo-Hamaoui, M., Danziger, Y., Frisch, A., Stein, D., Leor, S., Laufer, N., Carel, C., Fennig, S., Minoumi, M. Apter, A., Goldman, B., Barkai, G., Weizman, A. and Gak, E. (2002) Association between anorexia nervosa and the hsKCa3 gene: A family-based and case control study. Mol. Psychiatry 7, 82-85.

241 Koronyo-Hamaoui, M., Gak, E., Stein, D., Frisch, A., Danziger, Y., Leor, S., Michaelovsky, E., Laufer, N., Carel, C., Fennig, S., Mimouni, M., Apter, A., Goldman, B., Barkai, G. and Weizman, A. (2004) CAG repeat polymorphism within the $K C N N 3$ gene is a significant contributor to susceptibility to anorexia nervosa: A case-control study of female patients and several ethnic groups in the Israeli Jewish population. Am. J. Med. Genet. B Neuropsychiatr. Genet. 131, 76-80.

242 Koronyo-Hamaoui, M., Frisch, A., Stein, D., Denziger, Y., Leor, S., Michaelovsky, E., Laufer, N., Carel, C., Fennig, S., Mimouni, M., Ram, A., Zubery, E., Jeczmien, P., Apter, A., Weizman, A. and Gak, E. (2007) Dual contribution of NR2B subunit of NMDA receptor and SK3 $\mathrm{Ca}^{2+}$-activated $\mathrm{K}^{+}$ channel to genetic predisposition to anorexia nervosa. J. Psychiatr. Res. 41, 160-167.

243 Mossner, R., Weichselbaum, A., Marziniak, M., Freitag, C. M., Lesch, K. P., Sommer, C. and Meyer, J. (2005) A highly polymorphic poly-glutamine stretch in the potassium channel $K C N N 3$ in migraine. Headache $45,132-136$.

244 Curtain, R., Sundholm, J., Lea, R., Ovcaric, M., MacMillan, J. and Griffiths, L. (2005) Association analysis of a highly polymorphic CAG Repeat in the human potassium channel gene KCNN3 and migraine susceptibility. BMC Med. Genet. 6, 32

245 Grunnet, M., Jensen, B. S., Olesen, S. P. and Klaerke, D. A. (2001) Apamin interacts with all subtypes of cloned smallconductance $\mathrm{Ca}^{2+}$-activated $\mathrm{K}^{+}$channels. Pflugers Arch. 441, $544-550$

246 Castle, N. A., London, D. O., Creech, C., Fajloun, Z., Stocker, J. W. and Sabatier, J. M. (2003) Maurotoxin: A potent inhibitor of intermediate conductance $\mathrm{Ca}^{2+}$-activated potassium channels. Mol. Pharmacol. 63, 409-418.

247 Strobaek, D., Jorgensen, T. D., Christophersen, P., Ahring, P. K. and Olesen, S. P. (2000) Pharmacological characterization of small-conductance $\mathrm{Ca}^{2+}$-activated $\mathrm{K}^{+}$channels stably expressed in HEK 293 cells. Br. J. Pharmacol. 129, 991-999.

248 Shah, M. and Haylett, D. G. (2000) The pharmacology of hSK1 $\mathrm{Ca}^{2+}$-activated $\mathrm{K}^{+}$channels expressed in mammalian cell lines. Br. J. Pharmacol. 129, 627-630.
249 Dale, T. J., Cryan, J. E., Chen, M. X. and Trezise, D. J. (2002) Partial apamin sensitivity of human small conductance $\mathrm{Ca}^{2+}-$ activated $\mathrm{K}^{+}$channels stably expressed in Chinese hamster ovary cells. Naunyn-Schmiedebergs Arch. Pharmacol. 366, 470-477.

250 John, V. H., Dale, T. J., Hollands, E. C., Chen, M. X., Partington, L., Downie, D. L., Meadows, H. J. and Trezise, D. J. (2007) Novel 384-well population patch clamp electrophysiology assays for $\mathrm{Ca}^{2+}$-activated $\mathrm{K}^{+}$channels. J. Biomol. Screen. 12, 50-60.

251 Jager, H. and Grissmer, S. (2004) Characterization of the outer pore region of the apamin-sensitive $\mathrm{Ca}^{2+}$-activated $\mathrm{K}^{+}$ channel rSK2. Toxicon 43, 951-960.

252 Khawaled, R., Bruening-Wright, A., Adelman, J. P. and Maylie, J. (1999) Bicuculline block of small-conductance calcium-activated potassium channels. Pflugers Arch. 438, 314-321.

253 Fanger, C. M., Rauer, H., Neben, A. L., Miller, M. J., Rauer, H., Wulff, H., Rosa, J. C., Ganellin, C. R., Chandy, K. G. and Cahalan, M. D. (2001) Calcium-activated potassium channels sustain calcium signaling in T lymphocytes. Selective blockers and manipulated channel expression levels. J. Biol. Chem. 276, 12249-12256.

254 Scuvee-Moreau, J., Boland, A., Graulich, A., Van Overmeire, L., D'hoedt, D., Graulich-Lorge, F., Thomas, E., Abras, A., Stocker, M., Liegeois, J. F. and Seutin, V. (2004) Electrophysiological characterization of the SK channel blockers methyl-laudanosine and methyl-noscapine in cell lines and rat brain slices. Br. J. Pharmacol. 143, 753-764.

255 Monaghan, A. S., Benton, D. C., Bahia, P. K., Hosseini, R., Shah, Y. A., Haylett, D. G. and Moss, G. W. (2004) The SK3 subunit of small conductance $\mathrm{Ca}^{2+}$-activated $\mathrm{K}^{+}$channels interacts with both SK1 and SK2 subunits in a heterologous expression system. J. Biol. Chem. 279, 1003-1009.

256 Ghanshani, S., Wulff, H., Miller, M. J., Rohm, H., Neben, A., Gutman, G. A., Cahalan, M. D. and Chandy, K. G. (2000) Upregulation of the IKCa1 potassium channel during T-cell activation. Molecular mechanism and functional consequences. J. Biol. Chem. 275, 37137-37149.

257 Visan, V., Sabatier, J. M. and Grissmer, S. (2004) Block of maurotoxin and charybdotoxin on human intermediate-conductance calcium-activated potassium channels (hIKCa1). Toxicon 43, 973-980.

258 Mouhat, S., Visan, V., Ananthakrishnan, S., Wulff, H., Andreotti, N., Grissmer, S., Darbon, H., De Waard, M. and Sabatier, J. M. (2005) $\mathrm{K}^{+}$channel types targeted by synthetic OSK1, a toxin from Orthochirus scrobiculosus scorpion venom. Biochem. J. 385, 95-104.

259 Rauer, H., Pennington, M., Cahalan, M. and Chandy, K. G. (1999) Structural conservation of the pores of calciumactivated and voltage-gated potassium channels determined by a sea anemone toxin. J. Biol. Chem. 274, 21885-21892.

260 Wulff, H., Gutman, G. A., Cahalan, M. D. and Chandy, K. G. (2001) Delineation of the clotrimazole/TRAM-34 binding site on the intermediate conductance calcium-activated potassium channel, IKCa1. J. Biol. Chem. 276, 32040-32045.

261 Wulff, H., Miller, M. J., Hansel, W., Grissmer, S., Cahalan, M. D. and Chandy, K. G. (2000) Design of a potent and selective inhibitor of the intermediate-conductance $\mathrm{Ca}^{2+}$-activated $\mathrm{K}^{+}$ channel, IKCa1: A potential immunosuppressant. Proc. Natl. Acad. Sci. USA 97, 8151-8156.

262 Wittekindt, O. H., Schmitz, A., Lehmann-Horn, F., Hansel, W. and Grissmer, S. (2006) The human $\mathrm{Ca}^{2+}$-activated $\mathrm{K}^{+}$ channel, IK, can be blocked by the tricyclic antihistamine promethazine. Neuropharmacology 50, 458-467.

263 Rodriguez, F. A., Contreras, C., Bolanos-Garcia, V. and Allende, J. E. (2008) Protein kinase CK2 as an ectokinase: The role of the regulatory CK2beta subunit. Proc. Natl. Acad. Sci. USA $105,5693-5698$. 